\title{
Şeyh Süleyman Efendi ve "Lugat-i Çağatay ve Türkî-i Osmânî”ye tanık olarak katkıları
}

\section{Sevda KAMAN ${ }^{1}$}

\begin{abstract}
APA: Kaman, S. (2019). Şeyh Süleyman Efendi ve “Lugat-i Çağatay ve Türkî-i Osmânî”ye tanık olarak katkıları. RumeliDE Dil ve Edebiyat Araştırmaları Dergisi, (16), 69-97. DOI: 10.2900o/rumelide.616886
\end{abstract}

\section{$\ddot{\mathbf{O} z}$}

Buharalı aristokrat bir ailede yetişen, din adamı, elçi, diplomat, sözlük yazarı kimlikleriyle tanınan Şeyh Süleyman Efendi-i Özbekî el-Buhârî (1821-1890) kültürel ve siyasi hizmetlerinden dolayı pek çok kaynakta sıra dışı bir derviş olarak nitelendirilmiştir. Edebiyata, dile ve folklora düşkün biri olan Süleyman Efendi 1882 yılında Türk dilinin asıl edebî dili olarak Çağatay Türkçesini gören Tanzimat aydınları arasında oldukça ses getiren Lugat-i Çağatay ve Türkî-i Osmânî adlı sözlüğü yazmıştır. Sözlüğünde Nevâyî, Baykara, Lutfî, Agehî, Mûnis, Mir Haydar gibi tanınmış Çağatay şairlerinin şiirlerinden yararlanan Şeyh Süleyman Efendi otuz üç madde başına tanık olarak kendi şiirlerinden örnekleri sıralamış, şiirlerinde Nakşî mahlasını kullanmıştır. Çalışma, Süleyman Efendi’nin

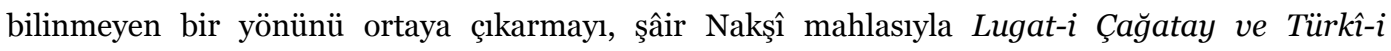
Osmânı̂ye tanık olarak katkılarını ve zengin sözcük dağarcığına sahip bir leksikografın şiirlerindeki sözcük seçimini tespit etmeyi amaçlamaktadır. Çalışmada Şeyh Süleyman Efendi’nin hayatı ve Lugati Çağatay ve Türkî-i Osmânî adlı sözlüğü hakkında bilgiler verilmiş, sözlüğünde tanık olarak kullandığı şiirleri ve şair kimliği üzerinde durulmuş, beyitlerde geçen sözcüklerin dizini ile özel adlar sözlüğü hazırlanmıştır. Buharalı dervişin şiirlerindeki göstergeler Orta Asya Türk kültürüne ve edebiyatına hâkim olduğuna, edebi dilini halk kültüründen ve günlük dilden beslenerek oluşturduğuna işaret etmektedir.

Anahtar kelimeler: Şeyh Süleyman Efendi, Lugat-i Çağatay ve Türkî-i Osmân̂̂, Nakşî, tanıklama, şiir.

\section{Sheikh Suleiman Efendi and his contributions to Lugat-i Chagatai and Turkî-i Osmânî using examples}

\begin{abstract}
Sheikh Suleiman Efendi Uzbek al-Bukhari (1821-1890), who grew up in an aristocratic family from Bukhara, and who was known as a reverend, ambassador, diplomat and dictionary writer, is described as an extraordinary dervish in many sources thanks to the cultural and political services that he provided. In 1882, Suleiman Efendi, who was fond of literature, language and folklore, wrote the dictionary called Lugat-i Chagatai and Turkî-i Osmânî, which was quite prominent among the Tanzimat intellectuals who regarded Chagatai language as the original literary language of the Turkish language. Sheikh Suleiman Efendi, who utilised the poems of well-known Chagatai poets like Nevâyî, Baykara, Lutfî, Agehî, Mûnis and Mir Haydar, listed the examples of his own poems per thirty-three items and used the Naqsi as his pseudonym in his poems. The study aims to reveal an unknown aspect of Suleiman Efendi by determining his contribution to Lugat-i Chagatai and Turkî-i Osmânî with examples, as well as determining the lexical choice of the poem with a rich vocabulary. In the study, informationed about the life of Sheikh Suleiman Efendi and his dictionary called Lugat-
\end{abstract}

1 Dr. Öğr. Üyesi, Bartın Üniversitesi, Edebiyat Fakültesi, Türk Dili ve Edebiyatı Bölümü (Bartı, Türkiye), skaman@bartin.edu.tr, ORCID ID: 0000-0001-8167-8961 [Makale kayıt tarihi: 17.03.2019-kabul tarihi:19.09.2019; DOI: 10.2900o/rumelide.616886] 
i Chagatai and Turkî-i Osmânî is provided, his poems used in his dictionary as examples and his poet identity are emphasized on, and a proper nouns dictionary is prepared using the index of the lexical items used in the couplets. The indicators in the poems of the dervish from Bukhara indicate to his knowledge of Central Asian Turkish culture and literature, and to the fact that he created his literary language by benefiting from folk culture and daily language.

Keywords: Sheikh Suleiman Efendi, Lugat-i Chagatai and Turkî-i Osmânî, Naksi, examples, poetry.

\section{Giriş}

\section{1. Şeyh Süleyman Efendi-i Özbekî el-Buhârî (1821-189o) ve eseri}

Asıl adı Hacı Şeyh Süleyman Efendi bin Kudretullah Efendi'dir; 1821'de Buhara'da Kunduz şehrine bağlı Karakul'da doğmuştur, babasının adı Kudretullah el-Kunduzî'dir ve annesi tarafından Abdullah Işan Karakulî ve Yahya Işan Türkmanî ile akrabalığı vardır (akt. Zarcone 2008: 54). ${ }^{27}$ Osmanlı arşivindeki İstanbul Tekkeleri Nüfus Vukuatı Vesikası'nda da "Dergâh-ı şerîf postnişini Hacı Süleyman Efendi b. Kudrettulah” Şeyh Süleyman Efendi Lugat-i Çağatay ve Türkî-i Osmânî adlı sözlügünün ön sözünde (1882: 2) Buharalı olduğunu, Osmanlının ikinci vatanı olduğunu ifade etmiştir.

Buhara Tekkesinin misafirlerinden Hokand elçisinin sözleri de Şeyh Süleyman Efendi’nin aristokrat bir aileden geldiğini göstermektedir:"Sultanahmet civarında Mehmet Paşa yokuşunda Özbekân hankâh-1 şerîfinin postnişini bulunan Şeyh Süleyman Efendi dâileri ebe'an-ceddin asilzâdegân-ı Buhara ve Hokand hükümdarının mâlûmâtları tahtında hânedân-ı kadîmden meşhur bir zât bulunduğu hâlde hasbelkader buraca mutavattın ederek ikamet etmekte ...” (BOA, MVL, nr. 485/109). Süleyman Efendi'nin Macaristan seyahatindeki (1877) heyette bulunan ve şeyhi yakından tanıma firsatı bulan Basiret gazetesi muhabiri Çaylak Mehmet Tevfik, eserinde eğitiminin bir kısmını İstanbul'da tamamlayan Şeyh Süleyman Efendi'yi hitabet sanatına hâkimiyeti ile tanıtmıştır: "Kendileri ilim ve fazl ile marûf olup hele edîbât-ı Fars ve Türk-i kadîme mensubiyeti vardır. Elsine-i selâsedde (dilde kolay ve akıcı anlatış) şiir inşâdına (topluluk önünde yüksek sesle okuma) kâdirdirler.” (1877: 62). Süleyman Efendi'nin Macaristan seyahatinde rehber olan Dr. Béla Erödi şeyhin ilginç bir şahsiyet olduğunu, kendisini Orta Asyalı Özbek olarak tanıttığını, doğum tarihini söylemediğini, seyahatlerini -Paris’ten Çin seddine kadar çocuk yaşından itibaren gezdiğini- ve bildiği dilleri övünerek anlattığını aktarmıştır (1877: 93).

Sûfî bir aileden gelen Şeyh Süleyman Efendi Buhara'da doğup gelişen ve Orta Asya'nın en yaygın tarikatı olan Nakşibendiyye'ye bağlıdır, Nakşibendi-Müceddidi tarikatının bir temsilcisidir (Zarcone 2008: 54, 57). Şeyh Süleyman Efendi 1844 yllında hac görevini yerine getirmek üzere Türkistan'dan Bağdat'a geçmiş, oradan da Hicaz'a gitmiş; Hicaz'da üç yıl kaldıktan sonra 1847 yllında Buhara emirinin İstanbul (Dersaâdet) elçisi (kapı kethüdası) olarak İstanbul'a gelmiştir (Tevfik 1877: 61). Daha sonra 11 Aralık 1874'te İstanbul'da Buharalı Nakşîbendi şeyhlerinin kurduğu Buhara Özbek Tekkesi’nin şeyhi (postnişini) olmuş, kısa sürede tekkeyi bir kültür-bilim merkezi hâline getirmiştir (Yeşilot, Çelik vd. 2015: 81-82). Şeyh Süleyman Efendi’nin Buhara Özbek Tekkesi’nin sadece din merkezi değil,19. yüzyılın

27 Şeyh Süleyman Efendi’nin Buhara Özbek Tekkesi'nde ağırladığı önemli âlimlerden biri olan Şihabüddin Mercânî (18181889) bu bilgileri günlüğünde paylaşmıștır. Sihabüddin Mercânı̂’nin 1886 ve 1887 yıllarında Orta Doğu'ya yaptı̆̆ seyahatlere dair tuttuğu günlüğ̈ü Rızeddin bin Fahreddin tarafindan Rıhletü'l-Mercânî (Rihlat al-Marcânî) başlı̆̆ıyla 1897'de Kazan'da basılmıştır (Şihabüddin Mercânî, Rihlat al-Marcânî, M. Chirkovoj, Kazan 1897). Ancak söz konusu esere ulaşılamadığı için Rıhletü'l-Mercânî'deki Şeyh Süleyman Efendi hakkındaki bilgiler Zarcone'nin bildirisi kaynak gösterilerek aktarılmıştır. 
ikinci yarısında Osmanlının siyasi ve kültür tarihinde önemli işlevleri olan bir kurum haline gelmesinde etkin bir rolü olmuştur.

Doğulu ve Batılı yolcuların, bilginlerin uğrak yeri Kadırga Özbekler Dergâhı, Özbekler Hangâhı, Buharî Tekkesi adları ile de anılan Buhara Özbek Tekkesi de Nakşîbendi dervişlerin İstanbul'da konakladığı tekkelerden biridir. ${ }^{28}$ Kadırga Küçük Ayasofya mahallesinde Şehit Mehmet Paşa Yokuşu'nda Sokullu Külliyesi'nin karşısında bulunan Buhara Özbek Tekkesi Nakşî dervişleri için H. 1104 (1692-93)'te İstanbul defterdarı İsmail Efendi tarafından kurulmuştur (Tanman 2007:121). Tekkenin 1878'de Sultan II. Abdülhamit’in emriyle tamir edildiğini bildiren Şeyh Süleyman Efendi’nin mahlası Nakşî’yi kullanarak yazdığı dört satırlık kitabe tekkenin yenilenmesi sırasında konmuştur:" "Ḥażrat-ı Abdulḩamīd Hān-ı 'adālat-pīşanın/'Omr ile ikbālini ḳılsın fuzūn rabb-ı macīd/Mülk-perver öyle bir sulțān-ı hayr-andīş kim/Sāyasında gün-be-gün vīrānalar oldı cadīd/Cumladan ta`mīra pek muhtāc idi bu hānkạāh/Étdi inşā himmetiyle oldı ıtmāma rasīd/Bu ımāratdır 'acab Nakşsi dédim tārīhnini/Şāh-ı Naḳşıband cāyını kıldı bınā Sulțān Hamīd (H. 1305 ). Bugün restore edilerek İstanbul Tasarım Merkezi adını alan Buhara Özbek Tekkesi'nin²9 19. yüzyılda Osmanlının Türkistan siyasetinde etkin bir kurum olarak rol almasında Süleyman Efendi’nin katkısı büyüktür.

Buharalı derviş, sonraki yıllarda Bâbıâli tarafından Osmanlının elçisi sıfatıyla 1868-1869 tarihinde Hindistan, Asya, Afganistan ve Buhara'ya gönderilmiştir. Şeyh Süleyman Efendi gönderildiği bölgelerdeki Müslümanlara Osmanlının gücünü hatırlatmış, oralardaki Rus ve Çin tehdidini gözlemlemiş, döndüğünde (1872) Buhara elçisi Abdülhay Efendiyle birlikte bir rapor (BOA, HR. TO, nr. 511/26) hazırlamıştır. Süleyman Efendi kendi hazırladığı ek raporda Buhara için gerekli gördüğü reformları beş başlıkta sıralamıştır. Bu ek rapor şeyhin bilim ve teknolojinin önemini kavradığını, eğitimde yenilikçi reformların gerekliliğini fark ettiğini de göstermektedir. ${ }^{0}$

Etkin bir dini lider olan Şeyh Süleyman Efendi’nin seyahatlerindeki İslam birliğini oluşturmak adına gerçekleştirdiği faaliyetlerine karşılık Meclis-i Muhâcirîn-i Çerâkese ve Meclis-i Meşâyih’in azalıkları verilmiştir (Tevfik 1877: 61). Bununla birlikte Şeyh Süleyman Efendi 1877'de savaş esnasında İstanbul'a gelen ve Gazi Osman Paşa'ya iftihar kılıcını getiren Macar heyetine iâde-yi ziyarette bulunmak, iki ülke arasındaki dostluğu ve ilişkileri geliştirmek üzere imparatorluk adına Macaristan'a giden on beş kişilik heyete başkanlık etmiştir. Peşte'de gerçekleştirilen Turan Kongresi'nde Sultan II. Abdülhamit’i temsil etmekle görevlendirilen şeyh, bu seyahatinde Türkmenlerle Türkler arasındaki bağın ırk ve dil birliği yoluyla güçlendirilmesi yönünde Panturanist çalışmalarda bulunmuş, bu hizmetlerine karşıllk üçüncü rütbeden mecidiye nişanına layık görülmüştür (Tevfik 1877: 61). Sultan II. Abdülhamit ırk, dil ve din birliği faaliyetlerinde Şeyh Süleyman Efendi’nin Orta Asya'daki nüfuzundan, Türk boyları arasındaki ruhani liderliğinden istifade etmek istemiştir.

Sultan II. Abdülhamit’in destekçisi olan Şeyh Süleyman Efendi Meclis-i Meşâyih Reisi Şeyh Osman Efendi, Ders Vekili Halil Efendi ve bazı meşâyih ile birlikte 1877-1878 Osmanlı Rus Savaşı öncesinde dünya Müslümanlarından maddi ve manevi destek almak için risaleler yazmıştır, sonrasında bu risaleler

28 Buhara Özbek Tekkesi dışında Eyüp’te, Beylerbeyi’nde, Üsküdar Bülbüldere'de ve Sultantepesi’nde olmak üzere dört Özbek tekkesi daha bulunmaktaydı (Yllmaz 2007: 3).

291925 yılı itibariyle 677 sayılı Kanun kapsamında kapatılan tekkeler arasında bulunan Buhara Özbek Tekkesi, Mustafa Kemal Atatürk tarafından verilen özel bir izinle faaliyetlerine devam etmiştir. Cumhuriyet döneminde zaman zaman kısmen metruk kalan binanın harem bölümünde ise son Seyh Abdurrahman Efendi ailesiyle birlikte ikamete devam etmiștir. Ahşap harem bölümü yanmış ve mescid-tevhidhane bakımsızlıktan harap olmaya başlamıştır. Özbekler Tekkesi, 1980' e kadar “Türkistanlılar Kültür ve Sosyal Yardım Derneği” ile "Türkistanlılar Talebe Yurdu”nu bünyesinde barındırmıstır (Safak 2011: 142-143).

Süleyman Efendi ve Ahdülhay Efendi'nin ortak raporları ile şeyhin müstakil yazdığı son rapor hakkında ayrıntılı bilgiler ve tespitler için bk. Okan Yeşilot, Yüksel Çelik vd. (komisyon), İstanbul'daki Türkistan Tekkeleri Ata Yurt ile Ana Yurt Arasındaki Manevi Köprüler, Türbeler Çeşmeler Taşınır Taşınmaz Kültür Varlıklarını Koruma ve Yaşatma Derneği, Şekil Ofset, İstanbul 2015, 105-107. 
onun vasıtasıyla Afganistan ve Hindistan taraflarına gönderilmiştir (Çetinsaya 1988: 43) Bu risaleler etkili olmuş, cüzi miktarda da olsa Hindistan'dan Osmanlıya destek verilmiştir.

Şeyh Süleyman Efendi’nin Özbekler Tekkesi’nin şeyhi, Osmanlının elçisi ve diplomatı olmak dışında çift taraflı ajanlığa soyunması da onun sıra dışı bir derviş olarak anılmasına neden olmuştur. Zira şeyhin Sultan II. Abdülhamit zamanında tekkeye gelen Orta Asyalı dervişlerden ve diplomatik seyahatlerinden edindiği izlenimleri, Osmanlının Orta Asya'daki faaliyetlerini İngilizlerle paylaşarak ajanlık yaptığı arşiv belgelerinden tespit edilmiştir. Şeyh Süleyman Efendi'nin İngilizlere verdiği raporlarda sağlıklı bilgiler yerine abartılı ifadeler aktardığı ve söylediklerinin birçoğunun gerçeği yansıtmadığı, bu sebeple İngilizlerin şeyhe güveninin azaldığı, istihbarata kıymet veren Sultan II. Abdülhamit'in durumdan haberinin olduğu yönündeki veriler şeyhin aslında Sultan II. Abdülhamit’in ajanı olduğu, çifte ajanlık yaparak Sultan II. Abdülhamit'in direktifleriyle İngilizlere yanlış bilgiler verdiği görüşünü desteklemektedir (Özcan 1992: 15). Nitekim 1880 tarihli İngiliz istihbarat raporundaki sözler şeyhin abartılı bilgileri rapor ettiğini doğrular niteliktedir:

\begin{abstract}
"Birçok defalar ben de şeyhin verdiği bilgiler hakkında tereddüt ettim. Onun nasıl istihbarat topladığını biliyoruz. Şeyhin İstanbul'daki tekkesi Asya'nın her tarafından gelen ziyaretçileri ağırlıyor. (...) Bu tekkeye uğrayarak bunlarla görüssme imkânı bulmuşlardı. Şeyhin raporları bu ziyaretçilerden edinilen bilgileri bize ulaştırmaktadır. Talimatımız üzerine bilgi toplarken daha dikkatli olmasını ve emin olmadığı şeyleri bize söylememesini şeyhe söyledik. (...) Birçok defalar şeyhin bize kıymetli bilgiler verdiğini biliyorum. Mesela saray... ile ilgili olanlar nispeten doğru çıtı. Ancak bazılarının hiç değerinin olmadığı açıkça ortadadır. Eğer biz ondan bilgi almaya devam edeceksek abartmalı olan birçok hususu burada tespit edebilmemiz sanırım mümkün olmayacaktır." (Özcan 1992: 14).
\end{abstract}

Sultan Abdülhamit’in Hatıra Defteri’nde Şeyh Süleyman Efendi diplomatik görevlerinden dolayı övgüyle anılmıştır:

"Hilâfet mevzuunda İngiliz teşebbüslerinin sonu gelmiş değildir. Çünkü Asya'da yüz elli milyon Müslümanı idareleri altında tutuyorlardı ve bu Müslümanlar üzerinde Hilâfetin büyük bir nüfuzu vardı. Bunu bildiğim için İngilizleri kuşkulandırmadan, her ihtimale karşı, seyyitler, şeyhler, dervişler gönderip Asya'daki Müslümanları hilâfete manen bağlamağa hususî bir itina gösteriyordum. Buharalı Şeyh Süleyman Efendi’nin Rusya'daki Müslümanlar arasında yaptığı hizmetleri bilhassa şükranla yâd ederim. Bunun, İngilizlerle münasebetlerimizde çok faydasını gördüm. Hindistan Umumî Valileri oradaki Müslümanların Osmanlı Devleti’yle yakından ilgilendiklerini gördükçe, hükümetlerine Osmanlılarla iyi geçinilmesini yazıyorlar ve böylece bizim işlerimizi bir nebze kolaylamış oluyorlardı." (Bozdağ 1992: 73-74).

Şeyh Süleyman Efendi’nin Macaristan seyahati oradaki halkın Çağatay Türkçesine olan yoğun ilgisini görmesi neticesinde sözlük yazmaya karar vermesine vesile olmuştur. Nitekim Lugat-i Çağatay ve Türkî-i Osmânînin manzum mukaddimesinin 64.-68. beyitlerinde sözlüğü yazmaya karar verişinin nedenlerini açılamıştır (1882: 11). Seyahati sonrası aldığı kararını hayata geçiren Şeyh Süleyman Efendi Lugat-i Çağatay ve Türkî-i Osmânî (1882) adlı sözlüğü yazmış, II. Abdülhamit, Şeyh Süleyman Efendi’yi Meclisi Meşâyı ve Encümeni Teftişi Maarif fahri üyesi yapmış ve Çağatayca-Osmanlıca sözlük hazırlamasından dolayı kendisine dördüncü rütbeden Osmanlı nişanı vermiştir.

Yenilikçi Şeyh Süleyman Efendi matbaacılı̆̆ da öğrenmiş, tekkede bulunan dervişlere bu hususta bildiklerini öğretmek istemiştir. Arşiv belgesinden (BOA, MF. MKT 3/75, 8 Ağustos 1872/3 C 1289) anlaşıldığı üzere Şeyh "Buhara ahâlisinden müstaid ve ehl-i kalem olanlara fenn-i tıba'at tahsil ettirilmek" amacıyla Matbaa-yı Âmire'den karşılanmak üzere ...iki mürettip, bir adet küçük hurufât destgâhı, bir adet taş destgâh ve 256 kg değerinde (200 kıye) madeni harfler" gibi bir takım isteklerde bulunmuş, masraflarının kendisi tarafından ödeneceğini belirtmiş, şeyhin talepleri Mekteb-i Sanayi’den temin edilerek bir senet karşılığında verilmiştir. Orta Asyalı şair ve mutasavvıfların eserlerini yayımlayan Şeyh Süleyman Efendi’nin ilk icraatı 1881-1882 yıllarında Hoca Ahmet Yesevî dışında 
tanınmış birçok Orta Asyalı Türk mutasavvıfının manzumelerine de yer verdiği Dîvân-ı Belâgat-Unvânı Sultânü'l-ârifin Hâce Ahmed Yesevî adlı 276 sayfalık bir nüsha yayımlamasıdır (Çakan 2005: 206). Zarcone'nin naklettiğine göre Şeyh Süleyman Efendi Sûfî Allah Yâr'ın Sebâtü’l-Acizîn adlı eserini Batı Türkçesine çevirmiştir, diğer eseri Feyzü'l-Necât'ı da yayımlamıştır (2008: 55). Bununla birlikte Ömer Han'ın Divan-ı Emir ve Mecmai'ş-şuara-i Asya-yı Vusta adlı eseri de H. 1300 (1884-1885 )'de Şeyh Süleyman Efendi tarafından basılmıştır.

Şihabüddin Mercânî, Kúnos gibi Doğulu ve Batılı bilginleri ağırlayan, devrinde iyi bir şöhreti olan, Türkistan misyonunu başarıyla yerine getiren şeyhin ölüm tarihi ile ilgili bir kayıt bulunmamaktadır. Şeyh Süleyman Efendi 1890 yılının Eylül ayına kadar meşihat makamında kalmış, ondan sonra bu makama Buharalı Mirza Âlim Efendi tayin edilmiştir (Yeşilot, Çelik vd., 2015: 82). Bu bilgiden hareketle şeyhin 1890 yllında öldüğü varsayılmaktadır. Sicill-i Osmânîde şeyhin Muharrem 1308'de (Ağustos Eylül 1890) vefat ettiği bilgisi vardır (Süreyya 1311: 101)

Şeyh Süleyman Efendi’nin Lugat-i Çağatay ve Türkî-i Osmânî adlı eseri Osmanlı sahasındaki Doğu Türkçesine ait ilk basılı sözlük unvanını taşımaktadır. Yazarının Buharalı oluşu ve iddialı mukaddimesi ile Osmanlı aydınının kısa zamanda dikkatini çekmiştir. H. 1298 (1882) tarihinde İstanbul'da Mihran Matbaası'nda basılan eserin iç kapağında birinci cildinin sözlük olduğu, ikinci cildinde ise Orta Asya'daki Türk boylarının edebiyatı ve atasözlerine dair bilgilerin bulunduğu belirtilmiştir.

Lugat-i Çağatay ve Türkî-i Osmânî ile ilgili tüm çalışmalar eserin birinci cildi esas alınarak hazırlanmıştır. Bu durum eserde bahsi geçen ikinci cildin hiç basılmadığını yani bitirilemediğini ya da kaybolma ihtimalini akıllara getirmektedir ancak sözlüğün "Müellifin Manzume-i Çağatayî Mukaddimesi" başlıkh manzum mukaddimesinin seksen üçüncü beytindeki "Bir bir altınca tizildi hemesi/Cild-i șānīde yazıldı hemesi” dizelerinde ikinci cildin yazıldığı işaret edilmiştir. Bununla birlikte eserin son sayfasında eserin birinci cildinin H. 1300 yılının Muharrem ayının sonlarında (1882/Kasım) tamamlandığı, Orta Asya'nın edebiyatına dair bilgileri içeren ikinci cildin yakın zamanda bitirilip basılacağı belirtilmiştir. Şeyh Süleyman Efendi’nin birinci cildin son sayfasındaki geleceğe dair bu temennileri ikinci cildin basılmamış olma ihtimalinin daha güçlü olduğunu göstermektedir:

"Lahu'l-ḩamd va'l-mınna işbu lugat kitābı dāru'l-ḩılāfa-ı 'alayh ve pāyıtaht-ı Konsțanținiyye'de hicret-i Nebeviyye’nin bin üç yüzinci senesi Muharramu'l-harāmın avāhırında hitāma rasīda oldı. Ba ‘̇̀ı āṣār-ı adabıyya ve Asyā-yı Vustā ahvvālına dāir olan cild-i șānīsi dahı dar-dast-ı tab“ olup ba'avnı-ta‘ālā ‘ahd-ı ḳarībde anı̀ dahıı ıtmāmı altāf-ı ilāhīdin ma‘mūldur.” (1882: 315).

Lugat-i Çağatay ve Türkî-i Osmânînin giriş bölümünde üç farklı mukaddime31 bulunmaktadır: Mukaddime, Mukaddime-i Çağatay, Müellifin Manzûme-i Çağatayî Mukaddimesi. İlk mukaddimede Şeyh Süleyman Efendi Çağatay Türkçesinin dünyadaki ana dillerden biri olduğunu, Orta Asya'daki kavimlerin bu dili konuştuğunu ifade etmiştir. Bu sebeplerle Osmanlı Türkçesinin aslı ve kaynağı olduğu için Çağatay Türkçesinin lâyıkıyla öğrenilmesinin lüzumunu açıklamaya gerek olmadığını belirtmiştir:

"Arbāb-ı lugat 'ındında ma lūm oldı̀̇ı vechle Çaġatay lısānı dunyāda bulunan ana lısānlardan biri olup Asyā-yı Vusțā'nın 'umūm ahālısı bununla mütekellimdir. İște bu cıhatla lısān-ı mežūrun ehemmiyeti derkārdır. Bı'l-hușūụs lısān-ı Türkī-yi 'Oșmānı̄'nin aṣıl ve ma'hażı olmaḳ munāsabatıyla Mamālik-i Maḩrūsa-ı Şāhāna'da ta'allum ve ı'tınāya şāyān oldığı muhtāe-ı beyān u ìzāḩ degildir.” (1882: 2).

Şeyh Süleyman Efendi benzer görüşleri eserin manzum mukaddimesinin seksen altıncı ve seksen yedinci beytinde de tekrar etmiştir: "İsmi Turkī-i Çag̉atay Lug̉atı/Kadīm 'Oșmānlı lısānıdur atı/Çag̉atay Türklerin aṣlıdur/Halīfa-ı rūy-ı zamīn naslıdur” (1882:11). Aslen Buharalı olduğunun altını çizen yazar

31 Lugat-i Çağatay ve Türkî-i Osmânînin mukaddimeleri 2.-20. sayfalar arasındadır. Mukaddimeden sonra iç kapak verilmiş, sözlük yine 2. sayfadan başlatılmıştır. 
ilk vatanının sözlüğünü ikinci vatanı kabul ettiği Osmanlıya yadigâr bırakmak istediğini, Osmanlının $A b u s ̧ k a$ adlı Çağatay sözlüğünü bildiğini ancak bu eserin kısa olduğunu söylemiştir. Kendi hazırladığı sözlüğün daha hacimli olduğunu ifade eden yazar, sözlüğünde Çağatay edebiyatının (Ali Şir Nevâyî, Hüseyin Baykara, Mir Haydar gibi) tanınmış şairlerinin gazel, naat, kasidelerinden örneklerini; Özbek, Türkmen, Kazak, Moğol, Kırgız, Kıpçak ve Kalmak gibi Çağatay dilini konuşan Türk boyları arasında kullanılan birçok atasözünü paylaştığını dile getirmiştir. Sözlüğünde ayrıca Çağatay dilinin kurallarını, morfolojik ve fonetik özelliklerini aktardığını belirten yazar ikinci cildin içeriğini açıklayan bir manzum mukaddime eklediğini de belirtmiştir (1882: 2-3). Mukaddime-i Çağatay'da methiyelerden sonra sözlüğünde yüzden fazla Orta Asyalı şairin eserlerinden tanıklı örnekler verdiğini ifade etmiştir. Nitekim manzum mukaddimenin yetmiş birinci beytinde bunu şöyle dile getirmiştir: "Bir mıșāl her luġata kéltürdüm/Şă‘ırı ismı bilen bildürdüm.” Ali Şir Nevayî, Hüseyin Baykara, Babur, Harezmî, Lütfî, Agehî, Mûnis, Ömer Han, Mahdum Kulu, Sûfî, Râcî gibi klasik dönem ve klasik sonrası Çağatay edebiyatının önde gelen şairlerinden örnekler vermekle birlikte Köroğlu, Fuzûlî, Nesimî gibi Batı Türkçesi şairlerinin şiirlerinden de yararlanarak şair yelpazesini geniş tutmuştur. Bu onun halk ve divan edebiyatıyla ilgilendiğini de göstermektedir. Şeyh Süleyman Efendi Abuşka'da olduğu gibi tanık olarak gösterilen örneklerde eser adlarını vermemiş, yalnızca şairin adını belirtmiştir. Bununla birlikte Şeyh Süleyman Efendi misal adıyla verilen alıntıların bazılarının sahiplerini belirtmemiştir. Kaçalin, Lugât-ı Çagatay ve Türki-i 'Osmânî adlı bildirisinde (2009: 108-115) bu alıntı sahiplerinin birçoğunu tespit etmiştir. Şeyh Süleyman Efendi sözlüğünün ikinci cildinde doksan iki Türk boyunun ve Tire Özbeklerinin kullanıldıkları Çağatayca atasözlerini alfabetik olarak sıraladığını bildirmiştir (1882: 4-7). Müellifin Manzume-i Çağataŷ̂ Mukaddimesi aruzun remel kalıbıyla yazılmış, doksan bir beyitten oluşan bir mesnevidir. Mukaddimenin on üçüncü beytine kadar Allah'a ve Peygamber A.S.'ye övgüler yer almaktadır. On dördüncü beyitten yirmi ikinci beyite kadar Sultan II. Abdülhamit'e methiyeler düzülmüştür. Mukaddimenin yirmi üçüncü beytinden altmış üçüncü beytine kadar şeyhin seyahatlerine dair bilgiler yer almaktadır. Şeyh Süleyman Efendi manzum mukaddimesinin son beyitlerinde Lugat-i Çağatay ve Türkî-i Osmânîyi hazırlama sebeplerini ve sözlüğün içeriği hakkında bilgiler vermiştir. Aslında beyitler önceki mukaddimelerde söylenenlerin tekrarı niteliğindedir. Manzumedeki bazı beyitler ise tanık cümleler olarak sözlükte de yer almıştır (1882: 8-10). Sözlüğün ikinci bölümü olan Kavâid adlı bölümde mukaddimede belirtildiği üzere Çağataycanın morfolojik ve fonetik özellikleri üzerinde durulmuştur. Üçüncü bölümde ise Arap alfabesine göre sıralanan 6754 sözcüğün madde başı olarak alındığı tanıklı sözlük yer almaktadır. Sözlüğün sonunda 124 sözcüğün yazım hatalarının ve doğrularının sıralandığı iki sayfalık bir "tashih listesi” yer almaktadır. Türkçülüğün Tarihi kitabında Buharalı Şeyh Süleyman Efendi'yi Türkçülüğün dil, folklor ve siyaset alanında hizmet verenlerden biri olarak gösteren Yusuf Akçuraoğlu sözlüğün mukaddimelerinden örnek cümlelere ve beyitlere yer vermiş; "Lugat-i Çağatay ve Türkî-i Osmânî mukaddimelerinden istihrâc ettiğimiz (çıardığımız) bütün vâkıalar Şeyh Süleyman Efendi'de velev bir mülhem olarak "Bütün Türklük” fikrinin varlığına delâlet ettikten başka İstanbul'da bazı mahâfilin (çevrelerin) hatta hükûmetin bu fikirden amelî siyâset sahasında istifadeye çalışmış olduğunu göstermektedir." diyerek Şeyh Süleyman Efendi'nin Türklük anlayışına işaret etmiştir (2015: 72).

Vambery, Şeyh Süleyman Efendi,'nin Çağatayca-Türkçe sözlüğünü Kelete Szemle dergisinden transkripsiyonlu olarak yayınlamıştır (Kushner 1998: 151). Sözlük, 1902'de Budapeşte'de Sejx Sulejman Efendi's Cagataj-Osmanisches adıyla Ignaz Kúnos tarafından kısaltılarak Almancaya çevrilmiştir. Kúnos, Ármin Vámbéry'nin yazdığı tavsiye mektubu vesilesi ile tanıştığı Şeyh Süleyman Efendi'den İstanbul'a geldiğinde birçok hususta yardım almıştır. Şeyh Süleyman Efendi'ye duyduğu vefa borcunu sözlüğün birinci cildini Almancaya çevirerek ödeyen Kúnos, yaptığı çeviride kısa bir ön sözden sonra 201 sayfalık sözlük bölümüne yer vermiştir. Kúnos, sözlükteki italik olarak verilen madde başlarını Latin alfabesine göre sıralamış; sözcüklerin karşısında Türkçe ve Almanca anlamlarını vermiştir (Ölmez 1998: 147). Çeviride tanık cümlelere yer verilmemiştir. Hasan Eren, bu çeviride önemli yanlışlıklar 
bulunduğunu ve dikkatle kullanılması gerektiğini belirtmiştir (Eren 1950: 146). Szinnyei’ye göre Kúnos, çeviri yaparken Çağatay Türkçesinin özelliklerine İstanbul Türkçesini kattığı için bu sözlüğün bilimsel değeri bulunmamaktadır (akt. Szilárd Szllágyı 2007: 178). Kúnos sözlüğün Almanca çevirisinin ön sözünde32 Şeyh Süleyman Efendi'nin sözlüğünün düzenlenmiş baskısı üzerinde çalışmasının sebeplerini şu şekilde açıklamıştır:

\begin{abstract}
"Birinci sebep, bu kitabın temin edilmesi en zor eserlerden biri olmasıydı. Ömrünün son yıllarında şahsi olarak iletişimde bulunduğum Şeyh Süleyman (Hiva doğumlu), büyük bölümü ölümünden sonra dikkat çekmiş olan eserinin az sayıda nüshasını yayımlamıştı. Bu eser Doğu ve Batı kitap piyasasının nadide parçalarındandır. İkinci olarak, özellikle Ural-Altay veya Türk unsurlarını dikkate alan, bu şekilde revize edilmiş bir baskıyı düzenleme arzusu beni buna yönlendirdi. Bu maksatla bu esere o kadar yoğunlaştım ki; yabancı, özellikle de Arapça ve Farsça kelimeleri mümkün olduğunca çıkardım ve bunların içinden sadece dile yerleşmiş olan kelimeleri bıraktım. Ayrıca, hem fonetik hem de anlam açısından Osmanlıca ile tamamen aynı olan ifadeleri de çıkardım. Kelimeleri tek tek açıllarken Arapça ve Farsça kelimelerin açıklamalarını da en gerekli olanlar kalacak şekilde azalttım. Ayrıca buna gerek duymamın bir başka nedeni ise Çağatayca kelimelerin güvenilir bir fonetik transkripsiyona ihtiyacı olduğunu görmemdir. Bu amaçla, yazarın İstanbul'da yaşayan üvey oğlu Abdullah ile iletişime geçtim, anahtar kelimeleri onun telaffuzundan sonra yazdım. Abdullah, İstanbul'da yaşamasına rağmen bazen babasının evinde şeyh ile bazen de şeyhin tekkesinde (Özbekler Tekkesi) hiç eksik olmayan Özbeklerle, en sevdiği ve en yaygın olan Çağataycayı aslında Özbek dilini konuşurdu. Bu nedenle onun telaffuzunun güvenilir olduğunu düşünüyorum. Buna rağmen kelimelerde hatalar varsa, bu eksiklikleri düzeltememiş olmamın sebebi İstanbul dilinin etkisidir. Aksi takdirde Süleyman Efendi'nin sözlügünün hataları vardır. Onun kendi kelime dağarcığından seçmediği birçok ifade vardı. Ondan duyduğum kadarıyla materyalleri toplama şekli şöyleydi: Tekkesinde onu ziyaret edenler, genellikle belli bir ücret karşılığında kendisine pek bilinmeyen ve farklı dil yapılarında kelime örnekleri sağladılar. Ancak bu durum kontrolsüzlüğü de beraberinde getirdi. Bu sebeple Türkçe olarak açıllanamayan ve kökeni şüphe uyandıran birçok ifade ortaya çıktı. Bu, Özbek dervişlerin ne kadar çok bilinmeyen kelime ve ifade söylerlerse şeyhe o kadar iyilik yapmış olacaklarına inandıklarını düşündürmektedir. Bir diğer rahatsız edici unsur ise, eş sesli kelimeler ile ifade edilen farklı kavramların bir anahtar kelime altında görünmesidir. Bu sorunu, farklı anlamlardaki kelimeleri noktalı virgül ile ayırarak çözmeye çalıştım. Tüm bunlara rağmen Şeyh'in sözlüğünün, özellikle Doğu Asya Türkçesinin sözlü eserlerinin sayısının hiç de çok olmadığg günümüz şartlarında, bilimsel amaçlar için gerekli eleştirilerde kullanılabilecek çok değerli bir dil malzemesi olduğunu inkâr etmek mümkün değildir.” (1902: 1-2).
\end{abstract}

Kúnos’un ön sözündeki bu tespitleri sözlükteki Özbekçe ve İstanbul dilinin etkisine dair (hem kendi çevirisine hem de Şeyh Süleyman Efendi'ye) yöneltilen eleştirilerin nedenini açıklar niteliktedir. Ayrıca sözlükteki bazı sözcüklerin "hiç tesadüf edilmeyen anlamları"nın olması yönündeki eleştirilere Şeyh Süleyman'ın tekkesinde misafir ettiği Özbek dervişlerin ne kadar çok bilinmeyen sözcük ve ifade söylerlerse şeyhe o kadar iyilik yapmış olacaklarına inanmalarının yol açtığını yani bu durumun sözlüğün derlem yöntemlerinden birinin sonucu olduğu anlaşllmaktadır. Bununla birlikte Kúnos'un ön sözü, kendisinin de Şeyh Süleyman Efendi'yi Lugat-i Çağatay ve Türkî-i Osmânînin söz varlığını oluşturma yöntemleri hususunda eleştirdiğini, sözlüğü birçok yönden hatalı bulduğunu, kendisinin bu hataları gidermek için şeyhin üvey oğlunun telaffuzundan yararlandığını, sözlüğe -eksikliklerine rağmen- değerli bir dil malzemesi olarak kıymet verdiğini göstermektedir.

Eren; Zenker, Budagov, Pavet de Courteille ve Şeyh Süleyman Efendi lügatlerinin mühim yanlışlarla dolu olduğunu, bu eserleri daima büyük bir dikkatle kullanmak ve sağlam tanıklarla kontrol etmek gerektiğini belirtmiştir (1950: 147). Fatih Erbay "Gölge Kelime Terimi ve Çağatayca Sözlüklerdeki Bazı Gölge Kelimeler” adlı makalesinde (2010: 1175-1186) Abuşka, Bedâyiü’l-Lugat, Senglâh, Dictionaire Turc Oriental, Lugat-i Çağatay ve Türkî-yi Osmânî, Cagataische Sprach Studien ve içinde Çağatayca sözcükleri de barındıran Versuch Eines Wörterbuches der Türk-Dialecte gibi sözlükleri tarayarak birtakım okuma hatalarından kaynaklı gölge kelimeleri tespit etmiş, çalışmasında Lugat-i Çağatay ve Türkî-i Osmânî'deki gölge kelimelerden birkaçını ele almıştır. Martin Hartmann da sözlükteki verilerin Çağataycayı değil Orta Asyadaki Özbekçe başta olmak üzere çağdaş şiveleri yansıttığını belirterek

\footnotetext{
32 Kúnos'un Almanca ön sözü bu makale için çevriltilmiştir. 
sözlüğü eleştirmiştir (Zarcone 2008: 56). Şen, Hartman’ın bu eleştirisini şu sözlerle haksız bulduğunu belirtmiştir:

\begin{abstract}
“Sözlük, Martin Hartmann tarafından Çağatay Türkçesinden ziyade Orta Asya'daki çağdaş şivelerin bir sözlüğü olduğu gerekçesiyle tenkit edilmișse de Mîr Alî Şîr Nevâî, Hüseyin Baykara, Mîr Haydar gibi ediplerin eserlerinin yanı sıra, Mâverâünnehir'de yaşayan halklar arasında kullanılan kelime, deyim ve atasözlerini de sözlüğüne dâhil ettiğini Şeyh Süleymân Efendinin zaten kendisi söylemektedir. Çünkü ona göre Çağatay Türkçesi hem Alî Şir Nevâî başta olmak üzere geçmişte klâsik Çağatay ediplerinin kullandığı bir dil, hem de bugün Mâverâünnehir'de yaşayan Özbek, Türkmen, Kazak, Moğol, Kırgız, Kıpçak ve Kalmak gibi halkların konuştuğu bir dildir.”(Şen 2014: 86).
\end{abstract}

Kúnos da hocası Budenz’e gönderdiği bir mektubunda (MİA. Belge Nr. 5448/262 I-II) şeyhle tekkedeki sohbetleri sırasında onunla ilgili edindiği izlenimleri aktarmış, şeyhin Türkçe hakkındaki bilgilerini eksik ve yanlış bulduğunu belirterek onu eleştirmiştir. Ona göre Şeyh Süleyman Efendi halkın konuştuğu Türkçeyi değersiz ve hor gören, buna karşılık Arapça ve Farsça sözcüklerin yanı sıra gramer kurallarına da fazla yer veren Osmanlıcayı öven biridir (akt. Szilárd Szılágyı 2007: 129).

Kaçalin, Lugât-ı Çagatay ve Türki-i Osmânî adlı bildirisinde bir asırdır el kitabı gibi kullanılan Şeyh Süleyman Efendi’nin sözlüğünün birtakım tertip hataları bulundurduğunu, sözlükte kelimenin çift imlası sebebiyle tekrarların, aynı bilgi ve tanımlar için tutarlı olmayan ifadelerin olduğunu; kelime kullanımına örnek verirken yapılan alıntıların kaynaklarının sağlıklı gösterilmediğini, bazı örneklerin yanlış maddelere yerleştirilmiş olduğunu, yanlış okumadan doğan ve abece sırasında yerli yerine oturtulmayan madde başı kelimelerin; c ve ç maddelerindeki kelimeler ile s ve ş maddelerindeki kelimelerin birbirinin içine girdiğini belirtmiştir (2009: 106). Kaçalin ayrıca Şeyh Süleyman Efendi'nin Pavet De Courteille'nin eseri Dictionnaire Turk-Orientali (1870) iskelet olarak alıp genişletmelerde bulunduğunu, Dictionnarre Turk-Oriental'in ise Niyâzînin El-lugatu'n-Neva'iyye ve'l-istişhadatu'lcagatäiyye'sine dayandığını ifade etmiştir (2009: 106). Samoyloviç de Şeyh Süleyman Efendi sözlüğünün Pavet de Courteille’inkini andırdığını ifade etmiştir (Caferoğlu 1984: 229). Osmanlıcadan Türkçeye Söz Karşılıkları Tarama Dergisi’nde Çağatay sözlükleri içerisinde en meşhuru olan Lugat-i Çağatay ve Türkî-i Osmânînin tekrar eden sözcüklerle beraber 7600 kadar sözcük içerdiği; Şeyh Süleyman’ın sözlüğü hazırlarken kaynaklarının adlarını açıklamadığını ancak Abuşka'yı esas olarak aldığının Hulasa-i Abbasî ile Vefik Paşa'nın Lehçe-i Osmânî’sinden yararlandığının anlaşıldığı belirtilmiştir (TDTC 1934: 63). Kaçalin, Lugât-ı Çagatay ve Türki-i Osmânî adlı bildirisinde eserin 6754 madde başı içerdiğini belirtmiştir (2009: 106). İslam Ansiklopedisi’ndeki "Sözlük” adlı makalede şu bilgiler mevcuttur:

\begin{abstract}
"Lugat-ı Çağatay ve Türki-i Osmani 6750 madde başı ihtiva eden sözlük Çağatay Türkçesi sözlükleri içerisinde en güvenilmez olanıdır. Eser, Pavet de Courteille'in sözlüğünün tanıklarıyla birlikte büyük ölçüde aktarılmasıyla Senglah'ın serbest bir çevirisinden meydana gelmiştir. Ancak müellif aktarma sırasında birçok hata yapmış, F. W. Radloff da Çağatayca kelimelerde Şeyh Süleyman'a dayandığı için (Versuch eines Wörterbuches der Türk-Dialecte, I-N, St. Petersburg 1 893-191 1) bu yanlışları tekrarlamıştır.” (Topaoğlu, Kaçalin 2009: 404).
\end{abstract}

Radloff, Versuch eines Wörterbuches der Türk-Dialecte’teki Çağatayca sözcükler için başvurduğu sözlüklerden biri olarak Lugât-ı Çagatay ve Türki-i Osmânîyi göstermiştir (Erbay, 2008: 245). Caferoğlu Lugât-ı Çagatay ve Türki-i Osmânî'deki söz varlı̆̆ını sözlüğün başlığı ile ilişkilendirerek şu şekilde eleştirmiştir:

Taşıdığı "Lügati Çağatay ve Türki Osmani” adına rağmen içerisine aldığı malzeme, Şeyh Süleyman Efendinin mensup olduğu Özbek şivesine göredir. Kaynakları muhtelif Çağatayca metinlerden alınmıştır. Orta Asya dervişlerinin canlı şivelerinden alınanları vardır. Eser, şüphesiz faydalıdır, fakat öz be öz Çağatayca sayılmaz.” (1984: 228). 
Tüm bu eleştirilere rağmen başvuru kitabı niteliğinde Osmanlı aydınlarından rağbet gören sözlüğe Atatürk de ilgi göstermiştir:

\begin{abstract}
“Atatürk Şeyh Süleyman'ın Çağatay Sözlüğ̈̈’ne önem vermiş ve bunun Türk harflerine çevrilerek yeniden basılmasını istemişti. Sözlük iki ay içinde yeni Türk harflerine çevrilmiş ama Abdülkadir İnan'ın, sözlüğün yeniden işlenmesi gerektiğine dair verdiği rapor üzerine Şubat 1933’te Abdülkadir İnan, Celal Sahir ve Besim Atalay'dan toplanan bir komisyon kurulmuștur. Eser yeniden gözden geçirilerek düzeltilmiş ve basılmak üzere Cumhuriyet Basımevi’ne verilmiştir. Sözlük ancak 4 forma basılmış, sonradan bu çalışmalar durmuştur." (Levend 1972: 418-419).
\end{abstract}

Osmanlıcadan Türkçeye Söz Karşılıkları Tarama Dergisi”ne de "Çağatay Lugatı, TDTC tarafından Türk alfabe ve yeni alfabe sırasıyla musahhah olarak yeniden bastırılmaktadır.” notu düşülmüştür (TDTC 1934: 64).

Eser üzerine Hüseyin Durgut'un hazırladığı Şeyh Süleyman Efendi-i Buhari Lügat-ı Çağatay ve Türkii Osmani (Cild-i Evvel) Adlı Eserin Transkripsiyonu33 (1995) adlı ve Yeşim Çakır'ın hazırladı̆̆ı Lugat-i Çağatay ve Türki-î Osmanî'nin Tematik Tasnifi (İsimler)34 (2018) adlı iki yüksek lisans tezi mevcuttur. Lugat-i Çağatay ve Türkî-i Osmânî, Hasan Abdullahi Cihani tarafından 2013 yılında Farsçaya Ferhangi Cağatayi-Farsi: Eser-i Şeyh Süleyman Efendi-yi Özbeki el-Buhari adıyla çevrilmiştir.

\title{
2. Şeyh Süleyman Efendi’nin “Lugat-i Çağatay ve Türkî-i Osmânîye tanık olarak katkıları
}

Lugat-i Çağatay ve Türkî-i Osmânî'de Orta Asyalı şairlerin şiirlerinden, atasözlerinden, deyimlerinden yararlanan Şeyh Süleyman Efendi bazen de kendi şiirlerini tanık olarak göstermiştir. Lugat-i Çağatay ve Türkî-i Osmânînin manzum mukaddimesinde yer alan "Nakş̧ī bitdim bu yosun üzre kitāb/Yārab olsun bu luġat her yere bāb" 35 (1882: 11) dizelerinde ve sözlüğün son madde başına verilen örneğe not düşülen "mișāl-i müellifihi Nakş̄” (1882: 315) açıklamasında mahlasını belirten Şeyh Süleyman Efendi’nin şiirlerinin toplu olarak yer aldığı bir eser ve şiirleri üzerine yapılmış bir çalışma tespit edilememiştir. Divan edebiyatında Nakşî mahlasını kullanan beş şair daha vardır: Nakşî Ali Akkirmânî (1065/1655), Nakşî İbrahim (1051/1641-1114/1702), Nakşî Mustafa (Edirneli), (?-?), Mustafa Nakşî Efendi (Eyyüplü)(1178/1764) ve Nakşî Ahmed (?-?) (Atik, 2005: 170). Atik, bu şairlerden Nakşî Ahmed'in bir ressam ve nakkaş olmasından dolayı, Nakşî Mustafa'nın da hattat olmasından dolayı mesleklerini göz önünde tutarak bu mahlasları kullandıklarını, diğer üçünün neden bu mahlası aldıkları hususunda net bir bilgi olmadığını belirtmiştir (2005: 170). Şeyh Süleyman Efendi’nin bu mahlası seçmesini Nakşibendiyye tarikatına bağlı olmasına ve dinî kimliği ile tanınmasına bağlamak mümkündür.

Çağatay edebiyatına vakıf olan Süleyman Efendi’nin şiir sevdasına dair Macaristan seyahatinde rehber olan Dr. Béla Erödi şu bilgileri aktarmıştır:

"Başka bir zaafı da şiirdi ve yazdığı şiirleri okumaktı. Çok defa gerçekten şaşmıştım güzel bir kafiyeyi tutturduğunda duyduğu çocukça sevince. Yemek sırasında kadeh kaldırılarak yapılan konuşmaları pek sevmezdi, oysa bunlar Macar şölen sofralarında uzar giderdi. İşte o zamanlar can sikıntısından şiir dizelerdi. O sırada yarattığı şiiri okuduğu birçok yemek şölenini hatırlıyorum. Bu şekilde yarattığı şiirlerini sonra odasında kâğıda geçirirdi. Burada bulunduğu sırada yazdığı şiirlerden en başarılısı 1 Mayıs günü öğleden sonra yazdığı bir rubai olmuştu. Bunun ilk beytini Gül Baba Türbesi’nin duvarına, tümünü ise akademinin ziyaretçi defterine yazmıştı. Rubai şöyleydi: Huda yâ ittifak üzre olanlar mülkin âbâd et/Macarla millet-i Osmâniyânı dem be dem şâd et/Hududundan çıan ağyara

33 Hüseyin Durgut, Şeyh Süleyman Efendi-i Buhari Lügat-ı Çağatay ve Türki-i Osmani (Cild-i Evvel) Adlı Eserin Transkripsiyonu, (Yayımlanmamıs Yüksek Lisans Tezi), Edirne: Trakya Üniversitesi Sosyal Bilimler Enstitüsü, 1995.

34 Yeşim Çakır, Lugat-i Çağatay ve Türki-î Osmanî'nin Tematik Tasnifi (İsimler), Yayımlanmamış Yüksek Lisans Tezi, Ankara: Ankara Hacı Bayram Veli Üniversitesi / Lisansüstü Eğitim Enstitüsü, 2018.

35 Bu dizeler sözlükteki "bāb" maddesine tanık olarak şu şekilde verilmiştir: "Bitdi Nakş̧ì bu yosun üzre kitāb/ Yā Rab olsun bu lugiat her yere bāb"( s. 66.) 
hergiz vermegin firsat/Rus-ı haini her yerde olsa kahr berbât et. Şiirlerinin kusursuz bir şekilde aktarılmasında son derece titiz davranırdı. Bunun içindir ki okurlara hatalı ulaşmasın diye yazılan şiiri defalarca okurdu. Memleketine hareket ettiği vakit tren kompartımanında da durmadan şiir yazdı. Venedik’ten gönderdiği şiirle dolu bir tomar kâğıda, bunları trende alelacele yazdığını, kabilse Macarcaya çevirerek kullanmam mesajını ilave etmişti. Bu şiirlerin çoğu Abdülkerim'in kılıcı ve Moskoflar konusundaydl." (1877: 114-115).

Béla Erödi’nin bu anıya 1877 yılında Csok Jasa! A Török Küldöttség Látogatásának Emlékkönyve adlı kitapta yer verdiği görülmektedir ancak söz konusu kitapta şeyhin ricasını yerine getirdiğine yani şeyhin verdiği şiirleri Macarcaya çevirdiğine dair bir bilgi yoktur. Mehmed Süreyyâ, Şeyh Süleyman Efendi'nin "yumuşak huylu ve şâir" olduğunu belirtmiştir (1311: 101). Zarcone, şeyhin edebiyata düşkünlüğünü ve Süleyman Efendi’nin bir ulema ya da bir sufi şeyh olmaktan çok bir edebiyatçı ve bir şair gibi görünmesini şu sebeplere bağlamıştır:

\begin{abstract}
"Ne tasavvufi eserler, ne de Kuran-ı Kerim tefsiri kaleme almadı, tam tersine Orta Asya edebiyatının bazı klasik kaynaklarının metinlerini hazırlayıp neşretti (Ahmet Yesevi, Sufi Allahyar) ve bir Çağatayca-Osmanlıca sözlüğü çıarttı. Öte yandan, Süleyman Efendi’nin tekkede düzenlediği ilmi sohbetlere ünlü ve üst tabakadan Osmanlı ve Tatar ulemaları katıldılar. Batı'dan gelmiş olan bilim adamları da Süleyman Efendi'yle görüştüler. Buhara Tekkesi’ni İstanbul'daki öbür Özbek tekkesi ile mukayese edersek mesela Üsküdar'da Sultantepe'deki dergâhtan oynadığı siyasi rol açısından daha önemlidir. Yalnızca tarihi yarımada da değil aslında bütün Osmanlıda hem diplomatik merkez ve uluslararası Türk dilleri ve edebiyatı üniversitesi, hem de bir ulema ve aydınlar mahfili modeline uygun çalışıp 19. asır ikinci yarısında Osmanlı fikir tarihinde önemli bir yer tutmuştur.” (2008: 57).
\end{abstract}

Matbaacılığı öğrenerek Orta Asya şairlerinin eserlerini yayımlayan Şeyh Süleyman Efendi’nin neden kendi şiirlerini derleyip yayımlamadığı bilinmemektedir. Özbek tekkesinin şeyhi olan Şeyh Süleyman Efendi’nin bu önemli görevi dışında elçilik vazifesiyle sık sık seyahat ettiği ve fahri diplomatlık yaptığı da göz önüne alınırsa şiirlerini derlemeye vakit bulamamış olması ihtimal dâhilindedir.

Bu çalışmada sözlükteki imzasız örneklerde Şeyh Süleyman Efendi’ye ait şiirler olup olmadığı bilinmediği için sadece Nakşî mahlaslı şiir örnekleri ve manzum mukaddimesinden alıntıladığı anlaşlan beyitler esas alınmıştır. Çalışmada söz konusu şiir örnekleri tanık olarak gösterildikleri madde başlarının alfabetik sırasına göre (Latin alfabesine göre) sıralanmış, madde başlarına karşılık verilen tanımlardan sonra sözcügün sözlükteki sayfa numarası gösterilmiş, şiirlerin ölçüsü (vezni) bulunmuştur. Bu bölümün sonunda Şeyh Süleyman Efendi’nin tanık olarak gösterdiği şiïlerde geçen bütün sözcüklerin (tanımlar dahil edilmemiştir) dizini ve özel adlar sözlüğü yer almaktadır.

Şeyh Süleyman Efendi’nin otuz üç madde başına tanık olarak kendi şiirlerinden verdiği örnekler şunlardır:

absam olmak: Ḳalaḳalmaḳ, sākit olmak (s. 2).

Her kimi körsen tavāzu’ ḳl ḩam ol

Köp kep urmaḳdın uyalġın absam ol

Fâ'ilâtün / fe'ilâtün / fâ'ilün

açaḳ: Ḳucak, āgūuss, kenār (s. 6).

Olup rāhda birbirine dūçār

Açaḳlaşdılar yığlap ol iki yār

Fe'ûlün / fe'ûlün / fe'ûlün / fe'ûl

arġūn, arg̉anūn: Bir nav` rubāb ve țanbūra nav'ından sāz ismidir. Arg̉ūn, Ḳılıç Arslan nām-ı pādşāhın og̉lıyla Hulāgu Hāānı og̉lı Aḳa Hูānıy og̉lı ismidir (s. 9). 
Daf u çeng u kemān u arğanūn ḳānūn u sanțūra

Calācīn u rubāb u gajak u nākūs u țanbūra

Mefâ'ilün / mefâ'ilün / mefâ'ilün / mefâ'ilün

Bu beyit Nedim'in "Ney u santur u rebâb ü def ü tanbûr ile çeng” (Gölpınarlı 1951: 382) mısrasını anımsatmaktadır.

atalık, atalıg: Babalıḳ, ubuvvat, murabbī, peder maḳāmında, pādşāhın tutdığı ve pederi gibi ı́tımād étdigi ‘ādam. Türkistān'da bir rutbadır. Atalı̀ ahālinin 'arż ve dādını ıstımā‘ éderek pādşāha tablīg ve 'arż étmeğe ve babalık șifatıyla muşfikāna hāl ve keyfiyetlerinden āgāh ve ḩabardār olmag̉a ma'mūrdur (s. 4).

Amīr luṭfinı teyri kördi layık

Tilev ibn Ḳllıc oldum atalık

Mefâ'îlün / mefấîlün / fe'ûlün

bāb: Yumn, sa‘ādat, fāl-ı hayr, munāsıb ve nikū, āsitāne, murād, ḳapu, darvāza ve éşik, cıhat (s. 66).

Bitdi Naḳşì bu yosun üzre kitāb

Yā Rab olsun bu lugiat her yere bāb

Fe’ilâtün (fầilatün) / fe'ilâtün / fe'ilün

Bu beyit sözlüğün manzum mukaddimesinin seksen dördüncü beytinde şu şekilde yer almaktadır: “Naḳşì bitdim bu yosun üzre kitāb/Yārab olsun bu luġat her yere bāb” (s. 11).

baḳmaḳ: Baḳmaḳ, naẓar, nigāh étmek, tābı', mulhāk olmak (s. 71).

Vacda-ı vaṣlııla bir ayyām ḳandurdın bizi

Baḳa baḳa baḳmadın āḩır ușanturdın bizi

Fe'ilâtün / fâ'ilâtün / fâ'ilâtün / fấilün

bārī: Teyri tacālā, canāb-ı hak, mavcūdluḳ, varlı̣̣ (s. 68).

Yéti iḳlīmda ba-'avn-ı bārī

Tün ü kün oldı şarīat cārī

Fe'ilâtün / fe'ilâtün / fe'ilün

Aynı beyit sözlüğün manzum mukaddimesinin onuncu beytinde de geçmektedir. Bu sebeple örneğin başında Nakşî mahlası kullanılmamıştır.

basmak: :Çiğnemek, pāy-māl étmek, ıstìlā ve hucūm étmek, gaālıb kelmek, pahş-kerden (s.68).

Közüm üzer ayaḳ bas külbe-i dīdamnı ét roşan

Ġubār-ı hāk-i pāyı̀ dīdama kuhll-ı sulaymānī

Mefâ'îlün / mefâ'illün / mefâ'illün / mefầîlün

bütün: Bütün, tamām, yek-pāra, yek-laḩt (s. 76).

Tā ki ārām étdi dıl yārın vafāsındın bütün

Çéktim él men cumla ‘ālam dıl-rubāsındın bütün

Fâ'ilâtün / fâ'ilâtün / fâ'ilâtün / fâ'ilün 
erük: Aṣvātdandur. Ḩumārı bağrıtmaḳ içün kullanılur. Yuha maḳāmında dahıııstı'māl olunur (s.10).

Zāhidī kördiler rryādur işi

May-parastlar ana dédi erük

Fe'ilâtün / mefâ'ilün / fe'ilün

élçilık: Rısālat, safārat (s. 58).

Élçilig birle sayāḩat étdüm

Hınd u Serhend'i ziyārat étdüm

Fe’ilâtün (Fâ'ilâtün) / fe'ilâtün / fe'iliün

Bu beyit manzum mukaddimenin yirmi dördüncü beytinde şu şekildedir: "Hem safāratla sayāhāāt ḳıldım/Hınd u Serhend’i zıyārat ḳıldım” Bu sebeple örneğin başında Nakşî mahlası kullanılmamıştır.

émiz: Sis, duman, buhār, mekānīden, tuman, bug (s. 62).

Ger yatīmī ḳalsa og̉ul yā ki ḳız

Özüy avlādın kébi anı émiz

Fâ'ilâtün / fâ'ilâtün / fấiliün

Burada madde başına verilen karşlıklardan sadece Farsça kökenli "mekânîden" emzirmek (Kara 2011: 171) anlamındadır. "Mekânîden" sözcüğü "émizmek" maddesinin karşllığı olarak da verilmiştir. Örnek beyitteki bağlama göre "Eğer oğul ya da kızdan bir yetim kalırsa, (yetimi) öz evladın gibi emzir" anlamı çıkmaktadır. Dolayısıyla bu örnek beytin "sis, buhar" anlamına gelen "émiz" maddesinden ziyade "emdirmek, emzirmek" anlamına gelen "émizmek” madde başının altında olması daha uygundur.

harās: Büyük degirmen, at ve ḩayvān ile döner (s. 167).

Ḩalk içinde dāna yanlig̉ yer ü kökdür bir ḩarās

Kim tüşerse ortasige sag̉ ḳalur étmen ḳıyās

Fâ'ilâtün / fâ'ilâtün / fâ'ilâtün / fâ'ilün

Harāt: Maksūrdur, Afg̈anıstān tavābıcātında Horāsān'da vāḳı 'Herī vılayatınıy merkez-i maşhūrı bir ḳal'a ismidir, ḳadīmda Arya ve Arban dénürdi, oh ma'nāsına sonra bu isim Īranīların dağıldığı vılāyatların cumlasına ta'mīm ve 'Irāḳ şekliyle taḳrīb olundı (s. 286).
Kandahār ile Harāt'ı kördüm
Dekken ü Balh'da köp olturdum
Mef'ûlü / mefâ'ilün / fe'ûlün

Bu beytin benzeri manzum mukaddimenin otuz beşinci beytinde şu şekildedir: "Kābil u Balh u Harāt’ kézdim/Mülk-i İrān u Kelat’’ kézdim." Ayrıca sözlükte "Kandahār” madde başına karşılık verilen imzasız örnekte ise "Kandahār ile Buhāāā kéttim/Şāh Nakş̧ibendī zıyārat éttim" (s. 230) beyti yer almaktadır. Bu beytin de Nakşîye ait olması muhtemeldir.

1şıł: Lam'a, nūr, żıyā, sırāe, rūşanī, aydın, mașābıh, partav (s. 54).

Külb[e]me? salġaç ışık ‘ārıżıdın

Kétti andūh u firāḳım yéridin

\footnotetext{
Adres | Adress 
Fe'ilâtün (Fâ'ilâtün) / fe'ilâtün / fe'ilün

kaydaġ: Nașll, ne gūna, ne cins, ne țarz, ne yajlığ, ne yolda (s. 225).

Ne müşkildür usun bu dahr-ara dīv u parī hem-reh

Raḳib-i bad-nıhāda hem-dem olmış ol șanam ḳaydag

Mefâ'îlün / mefâ'îlün / mefâ'îlün / mefâ'îlün

Kiş: Şahr-ı Sabz’ın ism-i ḳadīmı ve Amīr Timur’ın maḩall-ı mevlūdı bir şahrdır (s. 266).

Kiş mülkini sénsin arcumandı

Sādāt u saīd u sar-bulandı

Mef'ûlü / mefâ'ilün / fe'ûlün

kötel: Tag், köh, cabal, şa'b’ul-murūr band, geçid, suvārī, buland, nā-hemvār (s. 257).

Bir néçe köh-i köteldin aştım

Kābılın ḳorġanına yetiştim

Fâ'ilâtün / fe'ilâtün / fa'lün

Bu beyit sözlüğün manzum mukaddimesinin yirmi dokuzuncu beytinde şu şekildedir: "Bir néce raşu köteldin aşdım/Ķābılı ḳorǵanına yetişdim”. Bu sebeple örneğin başında Nakşî mahlası kullanılmamıştır.

körüyleşmek: Șohbbat ve mükālama étmek, ḳil u ḳāl ve muhhabbat eylemek, kepleşmek (s. 271).

Érler bilen körüyleşgen mard olur

Yaman bilen șuhbat tutgen țard olur

Mefầîlün / mefấîlün / fe'ûlün

munday: Munuy dék, mundaḳ, böyle şöyle (s. 280).

Mundayın pādşāh-1 țālı́ı on

Kelmemişdür ne kélür mundın son

Fe'ilâtün (fâ'ilâtün) / fe'ilâtün / fe'ilün

Aynı beyit sözlüğün manzum mukaddimesinin on yedinci beytinde de geçmektedir. Bu sebeple örneğin başında Nakşî mahlası kullanılmamıştır. Bu beyitteki övgüler Sultan Abdülhamit içindir.

ondak: O mınvāl, öyle, o rutba (s. 41).

Ondaḳ mundaḳ kişige sunmagin? boynını

Bütmes pöçek yayaḳdın toldurmasun ḳoynııı

Mef'ûlü / fâ'ilâtün / mef'ûlü / fâ'ilâtün

Bu beytin birinci dizesinde hece eksikliği vardır.

sayın: Sayı, ḩıāā, cam‘, şumāra eylemek (s. 185).

Dag்-ı ışḳıı sayısını Nakşi’dın sén sormaġıl 
Çun ḩısāb étsey felek ancumıdın³ yüz ḳat zıyād

Fâ'ilâtün / fâ'ilâtün / fâ'ilâtün / fâ'ilün

Burada “sayın” sözcüğü yerine "sayı” sözcüğü örneklenmiştir. Bu sebeple örnek beyit, "sayı” madde başının altında yer almalıdır.

téyrilik: Ilāhıyyat, hudāyī, șamadānī, cabarūtī, şab-dīzī, āfarīnış (s. 138).
Hamd o[l]sun teyri-yi bī-hem-tāga
Ol hudā-yı ahad-ı yektāga
Fe'ilâtün (fâ'ilâtün) / fe'ilâtün / fe'ilün

Aynı beyit sözlüğün manzum mukaddimesinin yetmiş dördüncü beytinde de geçmektedir. Bu sebeple örneğin başında Nakşî mahlası kullanılmamıştır.

tışḳarı: Ṭışarı, bīrūn, bara (s. 134).

İçkeride bir ḳaça dīvāna bar

Tışḳarıda bir néçe bīgāna bar

Müfteilün / müfteilün / fâ'ilün

turaḳ: Ṣabāt, sükūnet, mavḳı', vaḳfa, țur, hāl, hey’et (s. 115).

Kéce kündüz téprenüp sīm-āb ték

Munda yoḳ hacrinla ārām turaḳ

Fâ'ilâtün / fâ'ilâtün / fâi'lün

tuyuk: Tuyulmış, fāş u şuyū' olmış, baḩr-ı ramal ile musaddas, maḳșūr vaznında inşā olunan bir nav aş'ārdır. Bir lafẓ ile iki üç ma'nāya dalālat éder (s. 129).

Farż-1 'ayn u tuyuk u cura sözi

Öşük ü ḳoşuḳ ve kim Rabḡūzì

Fe'ilâtün/ fe'ilâtün / fe'ilün

Aynı beyit sözlüğün manzum mukaddimesinin onuncu beytinde de geçmektedir. Bu sebeple örneğin başında Nakşî mahlası kullanılmamıştır.

üstideki: Üzerindeki, favḳındakı (s. 33).

Labın üstideki hālın körenler țurfa hayrāndur

Ki bir hindū kılıp mesken kenār-ı çāh-ı zamzamda

Mefâ'illün / mefâ'illün / mefâ'îlün / mefâ'îlün

veh veh: Köpek, çaḳalın havlaması, hürmesi, sesi, 'af'af, kelime-i tahsīn, āfarīn dahıı olur, peh peh dahıı dénülür (s. 286).

Bāga hırām ḳıldı ol yār-ı sarv-ı kāmat

Veh veh bu ne tamāşā peh peh bu ne ḳyāmat

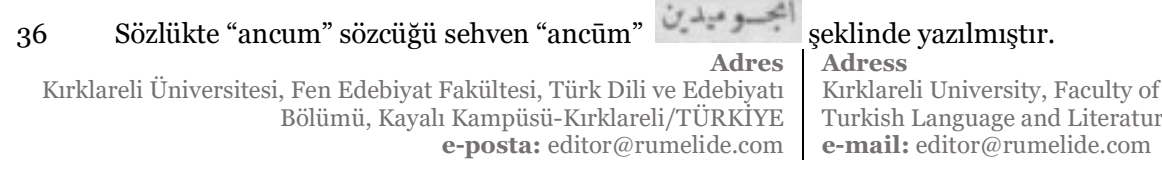


Mef'ûlü / mefâ'îlün / mef'ûlü / mefâ'îlün

yag̉ış: Yag̉mur, bārān, raḩmat, mațar (s. 296).

Yağış yagiıban tag் [u] dara güm boldı

Āmū ile Aras bahrı macdūm oldı

Fe'ûlün / fe'ûlün / fe'ûlün / fe'ûlün

yaratmak: Ḳuvvadan fila ketürmek, ḩalḳ, ıḩāṣ, ıbdā', ḩațr, ınşā, takvīn étmek (s. 290).

Munça ālamnı yaratğan bir ü bār

Yer [ü] kökni halk éten parvardgār

Fâ'ilâtün / fâ'ilâtün / fâ'ilün

yarlıg:: Manşūr, farmān, yarlık, tavḳ̄ị, nāma-ı humāyūn, 'amal-ı rutba, manșıb (s. 291).

Yarlıg [u] nāma vü ınşāsı bilen

Çaġatay lafzınıı ımlāsı bilen

Fe'ilâtün / fe'ilâtün / fe'ilün

Bu beyit sözlüğün manzum mukaddimesinin yetmiş dokuzuncu beytinde şu şekildedir:"Yarhig u nāma ve ınşāsı bilen/Çag̉atay rasmını ımlāsı bilen”. Bu sebeple örneğin başında Nakşî mahlası kullanılmamıştır.

yastanmak: Dayanmak, söyenmek, tekye étmek (s. 294).

Nāz ile ḳolınnı ḳoyma béline

Ḳılga yastanmak bolur mu ay nigār

Fâ'ilâtün / fâ'ilâtün / fâ'ilün

yiyti, yetti: Tamām oldı, nıhāyat boldı, tammat, vāṣıl oldı, yetişti, yetti, yedi, sab‘a, haft, yeti faḳat élvirdi, bas (s. 315).
Bu yerge çeh eyledim sar-ancām
Ḳıldım Çag̉atay lısānın ıtmām
Kilkim ucı bu mahalge yetti
Hatm oldı lugat bu yerde bitti
Mef'ûlü / mefâ'ilün / fe'ûlün

\section{1. Şeyh Süleyman Efendi’nin şiirlerindeki üslup ve dil özellikleri}

Şiirlerinde Nakşî mahlasını kullanan Şeyh Süleyman Efendi’nin Macaristan'da Gül Baba Türbesi ziyaretinde okuduğu şiir ile Macarcaya çevrilmesi için Dr. Béla Erödi’ye verdiği şiirlerin çoğu Abdülkerim'in kılıcı ve Moskoflar konusunda yazılmış siyasi içerikli şiirlerdir. Bu çalışmada ele alınan otuz üç madde başına karşılık örnek olarak verilen dizelere bakıldığında Şeyh Süleyman Efendi'nin şiirlerinde dini-tasavvufi unsurların ön plana çıkmadığı söylenebilir. Sözlükte "bārı̄”, "ténrilik" ve "yaratmaḳ" madde başlarına karşılık tanık olarak gösterilen beyitler dışında verilen örneklerdeki şiirler aşk, kahramanlık gibi din dışı konularda yazılmıştır. Şiir örneklerinin bazılarında ("absam olmaķ", "harās" ve "körüpleşmek" madde başlarına karşılık tanık olarak gösterilen beyitlerde) didaktik üslup kullanılmıştır. Şiirin şekil unsurlarına (uyağa ve ölçüye) önem veren Şeyh Süleyman Efendi’nin 
sözlüğüne tanık olarak gösterdiği şiirlerinin dili sadedir, şiirlerde Çağatay edebiyatının güçlü şairlerinin etkisi hissedilmektedir. Şeyh Süleyman Efendi başta imale olmak üzere zihaf, med ve ulama gibi aruz tasarruflarına başvurarak aruz ölçüsünün daha çok remel ve hezec kalıplarını kullanmış; teşbih, mübalağa, telmih, sihr-i helâl gibi söz sanatlarından da yararlanmıştır.

Şeyh Süleyman Efendi’nin şiirlerindeki otobiyografik unsurlara Dekken, Belh, Kandehar, Herat gibi diplomatlık göreviyle gezdiği yerlere yer vermesi ("élçilı̣̣" ve "Harāt" madde başlarına karşılık tanık olarak gösterilen beyitler) ve kendisini elçi olarak Hindistan, Asya, Afganistan ve Buhara’ya gönderen Sultan Abdülhamit’i övmesi ("munday" madde başına karşıllk tanık olarak gösterilen beyit) örnek gösterilebilir. Sözlükte tanık olarak gösterilen beyitlerden bazıları eserin 8.-10. sayfaları arasında yer alan manzum mukaddimesinden -bazen olduğu gibi bazen de ufak değişiklikler yapılarakalıntılanmıştır. Bu beyitlerin yer aldığı madde başları "bāb, bārī, élçilıḳ, kötel, munday, ténrilik, tuyuk, yarlığ”tır. Şeyh Süleyman Efendi bunlardan "bāb” maddesi dışındakilerde Nakşî mahlasını kullanmaya lüzum görmemiştir. Ayrıca "sayın" maddesine verilen örnek de imzasızdır ancak beytin içinde Nakşî mahlası geçmektedir. Diğer beyitlerde Nakşî veya misâl-i Nakşî ifadelerinden sonra beyitler yer almaktadır. Şeyh Süleyman Efendi'nin manzum mukaddimesinden alıntıladığı beyitler dışındaki yirmi altı beytin şiirlerinden (gazel ve kasidelerinden) seçtiği söylenebileceği gibi sadece sözlüğüne örnek teşkil etmesi için yazmış olabileceği de düşünülebilir. Zira şeyhin her firsatta -Gül Baba Türbesi’ni ziyaret ettiğinde, Özbekler Tekkesi tamir edildiği vakit kapı kitabesine yazılması için, Macaristan gezisinde, memleketine hareket ettiği vakit tren kompartımanında- şiir yazdığı kendisini tanıyanlarca ifade edilmiştir.

Şeyh Süleyman Efendi’nin şiirlerinin dil özellikleri Klasik Sonrası Çağatay Türkçesinin özelliklerini taşımaktadır. Bu sebeple çalışmada şiirlerin fonolojik ve morfolojik özellikleri üzerinde ayrıntılı olarak durulmamıştır. Şiirlerde geçen Klasik Sonrası Çağatay Türkçesinde nadir olarak kullanılan ekler

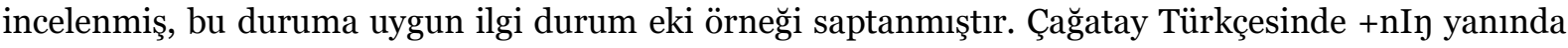
nadiren kullanılan $+\mathrm{nl} /+$ ni ilgi durum eki, şiirde sadece bir örnekte ("Kiş" madde başına tanık gösterilen şiirdeki "mülk+i+ni (266)" örneğinde) kullanılmıştır. Eckmann’a göre Çağatay Türkçesinde +nIy ilgi durum eki yerine bazen $+\mathrm{nl} /+$ ni ilgi durum ekinin kullanılması Özbek Türkçesinin etkisiyledir (2017: $68)$.

Şiirlerdeki Oğuzca unsurlar ise şunlardır: Yaklaşma durumu eki $+\dot{\mathrm{g} A},+\mathrm{gA}$ dışında birkaç örnekte +A'dır: "dīda+m+a (68)", "ḳorgan+1+n+a (257)", "bā $\dot{g}+a$ (286)". Yükleme durum eki +nI, ve +n dişında bir örnekte +1'dır: "Harāt+1 (286)". Benzetme edatı olan "ték (115)" yerine bir yerde "kébi (41)" geçmiştir. Şiirlerde "bol-" fiili yanında "ol-" fiilinin ve "té-" fiili yerine "dé-" fiilinin, "birle, bilen" edatlarıyla birlikte "ile” gibi Oğuzca unsurlara da rastlanılmaktadır. Ayrıca Oğuzcanın etkilerinden biri de şiirlerde Çağatay Türkçesinin bir özelliği olan iyelik üçüncü şahıstan sonra zamir n'sinin kullanılmadığı "yér+i+din (54)", “"ārı̇̇+1+dın (54)", "üst+i+de+ki (33)" gibi örneklerin yanında iyelik üçüncü şahıstan sonra durum eklerinden önce zamir n'sinin kullanıldığı "iç+i+n+de (167)", "vafā+sı $+n+d ı n ~(76)$ " gibi örneklere de yer verilmesidir.

Lugat-i Çağatay ve Türk̂̂-i Osmân̂̂”deki (makalenin birinci bölümünde değinilen) imlâ tutarsızlığını ve maddi imlâ hatalarını şiirlerde de görmek mümkündür. Örneğin sözlüğün genelindeki sözcükleri çift imlâlı ("yer/yér”, "kel-/kél-“, "yetiş-/yétiş-“ vs. gibi) yazma durumu Şeyh Süleyman Efendi’nin şiirlerinde de vardır. Çağatay Türkçesi metinlerinde karşllaşılan kalınlık-incelik uyumuna uymama hem alıntı ("maḩalge (315)" örneği ) hem de Türkçe kökenli sözcüklerde ("élçilı̀ (58)", "ortasige (167)", "tutgen (271)" örnekleri) görülmektedir. Dudak uyumunun tam olarak geliştiğini söylemek de mümkün değildir çünkü bazı sözcük veya eklerde uyuma aykırı kullanım görülmektedir: "kelmemişdür (280)", "ḳandurdın (71)", "ușanturdın (71)". 
Şeyh Süleyman Efendi’nin şiirlerinde geçen sözcüklerin dizini incelendiğinde toplam 284 sözcük tespit edilmiştir. Buna göre 17 özel adın dışındaki 267 sözcükten 128’i Türkçe, 76’sı Arapça, 62'si Farsça (bunlardan "erġanun ve külbe" Yunancadan Farsçaya geçen sözcüklerdir), 1’i Moğolcadır. Bu durum şiirdeki alıntı sözcük oranının \%52, Türkçe sözcük oranının \%48 olduğunu göstermektedir. Bu noktada Kúnos'un Şeyh Süleyman Efendi’yi Arapça-Farsça sözcüklerin kullanılmasında hassasiyet göstermediği yönündeki eleştirisini akıllara gelmektedir. Şüphesiz Çağataycayı tanıtmayı amaçlayan bir leksikografın şiirlerinde Türkçe kökenli sözcük oranının alıntı sözcük oranına göre daha düşük çıkmasında şiirlerin divan şiiri geleneğinde ve aruz ölçüsüyle yazılmasının payı vardır.

Şiirlerin söz varlığına bakıldığında "absam olmak, ayak basmak, el çekmek, güm bolmak, kep urmak, layık körmek" gibi deyimlerden, "hamd olsun” gibi ilişki (kalıp) sözünden; özel adlardan, Çağataycanın söz varlığından ve Arapça, Farsça, Moğolca kökenli alıntı sözcüklerden yararlanıldığı görülmektedir. Şiirlerindeki söz varlığı onun günlük dilden ve halk kültüründen beslendiğini, Orta Asya kültürüne, coğrafyasına, edebiyatına hâkim olduğunu ve iyi bir eğitim aldığını göstermektedir. Ayrıca yukarıda bahsedildiği üzere otobiyografik unsurların şiirlere etkisi de vardır.

\section{Dizin-Sözlük}

absam Sakit, uslu.

a. ol- Sessiz olmak. 2

açaḳlaş- Kucaklaşmak.

$$
\text { a.-dılar } 06
$$

ahad (<Ar. ehad) “Tek, bir" anlamında esmâ-i hüsnâdandır.

a.(hudā-yı a.-ı yek-tā) 138

āhır (<Ar. āhiir) Sonunda, âkıbet, nihâyet.
à. 71

‘ālam (<Ar. ‘àlem) 1. Âlem, kâinat, evren.
(ā.+nı 290
2. Herkes.
'à. (cumla 'ālam) 76

amīr $(<A r$. emīr) Emir, bey. 4

ancum $(<$ Ar. encum $)$ Yıldızlar.

a. $+1 \operatorname{lin} 185$

andūh (<Far. endūh) Gam, keder, tasa.

$$
\text { a. u firāk } 54
$$

ara İçinde, + da/+de.

a. 225

ārām (<Far.) Durma, dinlenme.

ā. 115

ā. ét- Durmak, kalmak. 76

arcumand (<Far. ercümend) Şerefli, haysiyetli, itibarl, muhterem.

a. +1266

arġanūn (Far. erganūn <Yun. organon) Org denen çalgı.
a. (kemān u a.) 9

‘ārı̇ $\left(<A r .{ }^{\prime a} r i z ̇\right)$ Yanak.

$$
\text { 'ā.+1dın } 54
$$

aş- (-den) Geçmek, geçip gelmek.

$$
\text { a.-tım } 257
$$

atalık Hükümdar nâibi, atabek.

$$
\text { a. ol- } 4
$$

avlād (<Ar. evlād) Evlat.

$$
\text { a. }+1062
$$

ay (Seslenme ünlemi) Ey!
a. 294

ayak Ayak.
a. 68.

'ayn bk. farż-1 'ayn 71

ba $(<$ Far. $)$ Kelime bașına getirilerek zarflar teşkil eden "ile, için,-e kadar, -e göre" anlaminda ön ek.

b.-'avn-ı bārī Allah’ın yardımıyla. 68

bāb $\quad(<A r$.$) Husus, mesele, konu$

b. ol- Konu olmak. 66

bad-nıhād (<Far. bed-nihād) Tabiatı, huyu fena olan, kötü huylu; zayıf karakterli.

b.+a (raḳib-ı b.) 225

bāg (<Far.) Bağ, bahçe.

b.+a 286

bahr $(<A r$.) Deniz, derya. b. +1296

bak- Bakmak.

$$
\begin{aligned}
& \text { b.-a } 71 \\
& \text { b.-madin } 71
\end{aligned}
$$

Krrklareli University, Faculty of Arts and Sciences, Department of Turkish Language and Literature, Kayalı Campus-Kırklareli/TURKEY e-mail: editor@rumelide.com 
bar Var, mevcut.
b. (2) 134

bār $b k$. bir ü bār

b. 290

bārī (<Ar.) Allah, yaratan, yaratıcı, "esmâ-i hüsnâdandır.

(ba-'avn-ı b.) 68

bas- Basmak. 68

bél Bel.

b.+ine 294

bīgāna (<Far. bìgāne) Yabancı.

b. 134

bī-hem-tā (<Far.) Eşsiz, benzersiz.

b. (tenri-yi b.) 138

bilen (Bağlama edatı) İle. Krş. ile
b. 271,291

bir Bir.

b. $71,167,257,134,134,33$

b. ü bār Tanrı. 290

birbiri Birbiri.

b. +ne 06

birle $b k$. ile. $K r$ ş. bilen, ile

b. 58

bit-(1) Tamamlanmak, sona ermek.

$$
\text { b.-ti } 315
$$

bit-(2) Yazmak.

$$
\text { b.-di } 66
$$

biz (Zamir) Biz.

$$
\text { b. }+\mathrm{i} 71
$$

bol- Olmak.

b.-dı (güm b.-) 296

b.-ur mu 294

boyun Boyun

b.+1j1 sun- 41

bu (Sifat) Bu.

b. $66,225,286,315$.

munça Bunca, bu kadar.

m. 290

munda Bunda.

m. 115

mundaḳ Böyle, bu şekilde.

m. 41

mundayın Böyle. m. 280

mundın Bundan.

m. soy Bundan sonra. 280

büt- Bitmek.

b.-mes 41

bütün Bütün.

b. 76

calācīn? Sözcük ilgili beyitte bir çeşit saz anlamında kullanılmıştır. ("Davulların, teflerin etrafındaki küçük çıngıraklar, çanlar” anlamına gelen Arapça kökenli "celācil" sözcüğü yerine yanlışlıkla yazılmış olabilir.)

c. u rubāb 09

cārī (<Ar.) Geçerli.

c. ol-Yürürlükte ve geçerli olmak. 68

cumla (<Ar. cumle) Bütün.

c. ‘ālam Herkes, insanlar. 76

cura (cüre) Eş, dost.

c. 129

çāh (<Far.) Kuyu, çukur.

ç. (kenār-ı ç.-1 zamzam) 33

çeh bk. çāh

ç. 315

çék- Çekmek.

ç. (él ç.-) 76

çeng $(<F a r$.) Kanuna benzeyen bir saz.

ç. (daf u c.) 09

çun $(<$ Far.) Çünkü.

ç. 185

daf $(<A r$. deff) Zilli bir kasnağa geçirilmiş kursak zarından oluşan çalgı.

d. u çeng 09

dag (<Far.) mec. Aşk, elem, keder vb. içe işleyen duyguların verdiği yanıklık, yara.

d.-1 'ışk 185

dahr (<Ar. dehr) Dünya.
d. 225

dāna (<Far. dāne) Tohum.
d. 167

dara (<Far. dere) Dere, küçük çay.

d. 296

dé- Demek.

d.- 10

dıl (<Far. dil) Gönül, yürek.

d. 76 
dıl-rubā (<Far. dil-rūba) Gönül kapan, herkesi kendine bağlayan, âşık olunan (güzel).

d. + sindin 76

dīvāna (<Far. dīvāne) Çıllgın, deli.
d. 134

dīda $(<$ Far. dīde) Göz.

d. + ma 68

d. + mnı (külbe-i d.) 68

div (<Far.) Şeytan.

d. u parī Şeytan ve cin. 225

dūçār (<Far.) Uğramış.

d. ol- Uğramak. 06

él El.

é. çék- Vazgeçmek. 76

élçilı̀ Elçilik.

é. 58

émiz- Süt emdirmek.

i. 62

ér Erkek.

é.+ler 271

erük Sarhoşu bağırtmak için kullanılan yuhe makamında bir söz.

e. 10

ét- (Yardımcı fiil) Etmek.

é.-(roşan é.-) 68

é.-di (ārām é.-) 76

é.-düm (sayāhat é.-) 58

é.-düm (zıyārat é.-)58

é.-en (halḳ é.-) 290

é.-men (ḳ̂yās é.-) 167

é.-sey (hısāb é.-) 185

eyle- (Yardımcı fiil) Eylemek.

e.-dim (sarancām e.-) 315

farż $A r$. Farz.

f.-1 'ayn İslâm dîninde her mükellef müslüman tarafindan bizzat yapılması gereken (beş vakit namaz, oruç vb.) farz. 129

felek (<Ar.) Gökyüzü.

f. 185

firāḳ (<Ar.) Hüzün, teessür.

f.+1m (andūh u f.) 54

gajak Orta Asya Türklerinde "gacek, gıcak, gıccek veya gijek" diye de anılan bir tür saz ve çalgı, kabak kemane.

g. u nākūs u țanbura og ger $(<$ Far. $)$ Ĕger.

g. 62

gubār $(<A r$.$) Toz, ince toprak.$

g.-1 hāk-i pāy Ayağın bastığı toprağın tozu. 68

güm Kayıp, yitik.

g. bol- Kaybolmak, görünmez olmak. 296

hacr (<Ar. hecr) Ayrilık.

h.+1nla 115

hāak (<Far.) Toprak.

h.. (g்ubār-ı h..-i pāy) 68

hāl (<Far.) Vücuttaki küçük esmer benek, ben.

h. + in 33

halk ( $<A r$.) İnsanlar.

h. 167

halk (<Ar.) Yaratma.

h. ét- Yaratmak. 290

ham (<Far.) Eğri, bükülmüş.

h. ol- Eğrilmek, bükülmek. 2

hamd (<Ar.) Şükür.

h. olsun Allah'a şükürler olsun. 138

harās (<Far.) Hayvan döndürülen değirmen.

h. 167

hatm Bitirme, sona erdirme.

h. ol- Bitmek, sona ermek. 315

hayrān $(<A r$.) Hayran, şaşkın.

h. + dur 33

hem-dem (<Far.) Dost, arkadaş.

h. ol- Dost olmak. 225

hem-reh $(<$ Far.) Yoldaş.

h. ol- Yol arkadaşlı̆̆ı yapmak. 225

her $\quad(<$ Far. $)$ Her, her biri.

h. 66

h. kim Hangi kimse, her kim. 2

hırām (<Ar.) Salınarak gidiş.

h. kıll- Salınarak yürümek. 286

hısāb $(<A r$.) Hesap.

h. ét- Hesaplamak. 185

hind̄̄u(<Far.) Yüzdeki ve vücuttaki ben.

h. 33

lbn $\quad(<A r$.) Oğul.

1. (Tilev ibn Ḳılıc) 4

1ḳlīm $(<A r$.) Diyar, ülke. 
Sheikh Suleiman Efendi and his contributions to Lugat-i Chagatai and Turkî-i Osmânî using examples / S. Kaman (p. 69-97)

$1 .+$ da 68

imlā (<Ar.) İmlâ, yazım.

$1 .+$ S1 291

inşā (<Ar.) Süslü, secîli nesir.

$1 .+$ S1 291

1şık Işık, aydınlık.

1. sal- Işık yaymak, aydınlatmak. 54

'1şk (<Ar.) Aşk.

$1 .+1 \eta($ dag -1 ' 1.) 185

1tmām $(<A r$.) Tamamlama.

ı. kıl- Tamamlamak. 315

iç İç.

i.+inde 167

içkeri İçeri.

i. + de 134

iki İki.

i. 06

ile İle. $K r s$ s. birle, bilen

i. $286,294,296$

iş İş, davranıs.

i. $+\mathrm{i} 10$

kaça Kaç tane.

k. 134

kal- Kalmak

k. (yatīmī ḳ.-) 62

k. (sag k..-) 167

kāmat ( $<A r$.) Boy, endam.

k. (yār-ı sarv-ı k.) 286

kandur- Kandırmak, aldatmak.

k. -dın 71

kạanūn (<Ar.) Çalgı aleti.

k. u sanțura og

kat Kat, defa, kere.

k. (yüz ḳat) 185

kaydag $\mathrm{Ne}$ cins, ne tarz.

k. 225

kébi Gibi.

k. 62

kéce Gece

k. kündüz 115

kep Söz.

k. ur- Söz söylemek. 2 kel- Gelmek. Krş. kél-

k.-memişdür 280

kél- bk. kel-

k.-ür 280

kemān (<Far.) Keman, bir tür çalgı.

k. u argāanūn 09

kenār $(<F a r$.$) Kenar.$

k.-1 çāh-1 zamzam 33

két- Gitmek

k.-ti 54

kıl Tüy.

k..+ga 294

kıl- (Yardımeı fiil) Kılmak, etmek.

k. (tavāzu' k..) 2

k..-dı (hırām ḳ.) 286

k..-dım (ıtmām ḳ.) 315

k..-1p (mesken k.-) 33

ḳıāmat (<Ar. kìyāmet) Gürültülü karışıklık, kaynaşma, gürültü, patırtı, velvele.

k. 286

ḳıās (<Ar.) Karşılaştırma

k. ét- Karşılaştırmak. 167

ḳı Kız, kız çocuk.

k. 62

ki $\quad(<F a r$.$) Ki. K r s ̧$. kim

k. 33

k. (yā ki) 62

k. (tā k.) 76

kilk (<Far.) Kalem.

k. + im 315

$\operatorname{kim}(1) \quad b k . \mathbf{k i}$

k. 129

kim (2) Hangi kimse.

k. 167

k.+i (her kim). 2

kişi Kişi.

k. + ge 41

kitāb (<Ar.) Kitap. Şiirde kitap sözcüğü ile Lugat-i Çağatay ve Türk̂̂-i Osmânî kastedilmektedir.

k. 66

kol El.

k.+1nnı 294

korġan Kale. 
k..+1na 257

ḳoşuḳKoşuk, koşma, türkü.

k. (öşük ü k.) 129

ḳoy- Koymak, yerleştirmek.

k.-ma 294

ḳoyun Gögüs, kucak.

k. +10141

köh (<Far. kūh) Dağ.

k.-i kötel 257

kök Gök.

k.+dür (yer ü k.) 167

k. + ni 290

köp Çok.

k. 2,286

kör- Görmek

k.-di (lāyık k.) 4

k.-diler 10

k.-düm 286

k.-enler 33

k.-sen 2

körüyleş- Sohbet etmek.

k.-gen 271

kötel Geçit, tepe.

k.+din (köh-i k.) 257

köz Göz.

k.+üm 68

kuhl (<Ar.) Göze çekilen sürme.

k.-1 sulaymānī 68

külbe? (Fars. kulbe < Yun.) Kulübe, gam tasa evi.

k.+me 54

k.-i dīda 68

kün $b k$. kündüz.

k. (tün ü k.) 68

kündüz Gündüz. Krş. kün

k. (kéce k.) 115

lab (<Far. leb) Dudak.

$1 .+1033$

lafz $(<A r$.) Söz.

l.+1nın 291

lāyı $(<A r$.) Uygun.

l. kör- Uygun bulmak. 4

lısān $(<A r$.) Dil.
$1 .+\ln 315$

lugat (<Ar.) Sözlük. Şiirde lügat sözcüğü ile Lugat$i$ Çağatay ve Türkî̀-i Osmânî kastedilmektedir.

1. 66,315

luṭf (<Ar.) İyilik, ihsan.

1. $+\ln 14$

ma'dūm $(<A r$.) Yok olan, bulunmayan.

m. ol- Yok olmak. 296

maóal ( $<A r$.) Yer, kısım.

m.+ge 315

mard (<Far. merd) Yiğit.

m. ol- Yiğit olmak. 271

may-parast (<Far. mey-perest) Ayyaş, durmadan şarap içen.

m. + lar 10

men Ben.

m. 76

mesken $(<A r$.) Yer, ev.

m. kıl- Bir yere yerleşmek. 33

mu Soru edatı.

m. (bolur mu?) 294

mülk $(<A r$.) Diyar.

m.+ini 266

müşkil (<Ar. muşkil) Zor, güç.

m.+dür 225

nākūs (<Ar.) Kilise çanı

n. (gajak u n. u țanbura) 09

nāma (<Far.) Ferman.

n. 291

nāz (<Far.) Naz, cilve.

n. 294

ne 1 . (sıfat) Nasıl.

n. 225

2. (zamir) Hangi şey.

n. 280

3. (zarf) Şaşma veya abartı bildiren bir söz

néçe Nice, ne kadar.

n. 134,257

nigār (<Far.) Resim gibi güzel sevgili:
n. 294

oġul Oğul.

o. 62 
ol (Sifat) O.

o. $06,138,225,286$

anı Onu.
a. 62

aya Ona.
a. 10

ol- (Yardimcı fiil) Olmak.
o. (absam o.-) 2
o. (ham o.-) 2
o.-dı (cārī o.-) 68
o.-dl (hatm o.-) 315
o.-dı (macdūm o.-) 296
o.-dum (atalık o.-) 4
o.-mış (hem-dam o.-) 225
o.-up (dūçār o.-) 06
o.-ur (mard o.-) 271
o.-ur (țard o.-) 271
o.-sun (bāb o.-) 66
o.-sun (hamd o.-) 138

oltur-Oturmak.

o.-dum 286

ondak Öyle, o tarz, o suret.

o. 41

oy Önce.
o. 280

orta Orta.

o.+sige 167

öşük Masal, hikâye.

ö. ü ḳoşuk 129

öz Kendi.

ö.+ün 62

pādşāh (<Far.) Padişah.

p.-1 țālı` 280

parī (<Far. perī) Peri.

p. (dīv u p.) 225

parvardgār $(<F a r$. perverd-gār) Tanrı, yaratan.

p. 290

pāy (<Far.) Ayak.

p.+ın (gubār-ı hāk-i p.) 68

peh peh (Ünlem) Beğenme, takdir, şaşma vb. duyguları anlatı.

p. 286

pöçek (<Far. pūçek) Pul. p. 41

rāh (<Far.) Yol.

r.+da 06

raḳīb $(<A r$.) Rakip.

r.-1 bad-nıhād 225

rıyā (<Ar. riyā') Riya, ikiyüzlülük.

r. + dur 10

rubāb $(<$ Far. rebāb) Rebab, tambur şeklinde kısa sapli saz.

r. (calācīn u r.) 09

roşan (<Far. rūşen) Parlak, açık, belli.

r. ét- Aydınlatmak. 68

sādāt (<Ar.) Seyitler.

s. u saîd u sar-buland 266

sag் Sağ.

s. ḳal- Sağ ve salim kalmak. 167

saīid ( $<A r$.) Mutlu ve uğurlu.

s. (sādāt u s. u sar-buland) 266

sal- Salmak

s.-ġaç (1şık s.-) 54

șanam (<Ar.șanem) mec. Çok güzel.

ș. 225

sanțura (<Far. sanțur-sentūr) Tellerine iki küçük tokmakla vurulmak suretiyle çalınan kanuna benzer çalg1.

s. (ḳānūn u s.) 09

sarancām (<Far. ser-encām) Son.

s. eyle- 315

sarv (<Far. serv) mec. Boyu, endâmı böyle bir serviyi andıran sevgili.

s. (yār-1 s.-1 ḳāmat) 286

sayāhat $(<A r$. siyāhat) Seyahat.

s. ét- Seyahat etmek. 58

sayı Sayı.

S. + Sinı 185

sén (Zamir) Sen.
S. 185
s. $+\sin 266$

sīm-āb $(<$ Far.) Clva.

$$
\text { S. } 115
$$

soy Sonra.

s. (mundin s.) 280

sor- Sormak.

S.-mağll 185 
söz Söz.

S. $+\mathrm{i} 129$

șubbbat (<Ar. șuhbat) Sohbet.

ș. tut- 271

sun- Boyun sunmak, uzatmak.

s.-magin (boyun sun-) 41

sulaymān̄̄ (<Ar.) Ezheri taşından daha kötü bir pîrûze çeşidi.

s. (kuhl-1 s.) 68

şarī'at ( $<A r$. şeri‘at) Şeriat, Allah'in emri olan din kaideleri.

ş. 68

tā $\quad(<$ Far. $)($ Zarf $)$-a kadar.

t. ki -a kadar,-ıncaya kadar. 76

tag Dağ.

t. 296

tālı' $\quad(<A r . t ̦ a ̄ l i c)$ Talih.

ț.+1 (pādşāh-1 ț.) 280

tamāşā (<Far. temāşā) Bakıp seyretme, gezme yürüme.

t. 286

țanbura (<Ar.țanbūr) Klasik Türk müziğinin başlıca çalgılarından biri olan, yay veya mızrapla çalınan, uzun saplı, telli çalgı.

ț. (gajak u nākūs u țanbura) o9

țard $(<A r$.$) Kovma.$

ț. ol- Kovulmak. 271

tavāzu' (<Ar. tevāżu') Alçakgönüllük.

t. ḳıl- Alçakgönüllük gösterme. 2

ték Dek.

t. 115

tépren- Teprenmek, kımıldanmak.

t.-üp 115

tışkạarı Dışarı.

t. + da 134

toldur- Doldurmak

t.-masun 41

turak Durak

t. 115

turfa ( $<$ Ar. țurfe) Görülmemiş.

ț. 33

tut- Tutmak

t.-gen (șuhbat t.-) 271

tuyuk Kısa vezinle söylenen bir tür şiir, iki üç manayı gösteren söz. t. (farż-1 ‘ayn u t.) 129

tün Gece.

t. ü kün Gece ve gündüz. 68

tüş- Düşmek.

t.-erse 167

u (<Far.) bk. ü, vü, ve

u. 58, 09

u. (daf u çeng) 09

u. (kemān u arḡānūn) o9

u. kāānūn u sanțura 09

u. (calācīn u rubāb) 09

u. (ǵajak u nākūs u țanbura) o9

u. (andūh u firāḳ) 54

u. (dīv u parī) 225

u. (farż-1 'ayn u tuyuḳ) 129

u. (sādāt u sa'̄id u sar-buland) 266

uc Uç.

u. +1315

ur- Vurmak.

u.-makdın (kep u.-) 2

uṣantur- Usandurmak.

u.-din 71

usun $\mathrm{O}$ taraf, o yön.

u. 225

uyal- Utanmak.

u.-gin 2

ii $\quad(<F a r) b$.$k . ve$

ü. (bir ü bār) 290

ü. (Dekken ü Balh) 286
ü. (öşük ü ḳoşuk) 129
ü. (tün ü kün) 68
ü. (yer ü kök) 167

üst Üst.

ü.+ideki 33

üzer Üst, her şeyin yukarısı, üzeri.

ü. 68

üzre Üzerinde, için.

ü. 66

va'da $\left(<A r . v a^{\prime} d e\right)$ Vade, mühlet.

v.-1 vaṣl Kavuşma için verilen zaman. 71

vafā (<Ar vefā') Vefa, sözünde durma.

v.+sindin 76

Kurklareli University, Faculty of Arts and Sciences, Department of Turkish Language and Literature, Kayalı Campus-Kırklareli/TURKEY e-mail: editor@rumelide.com 
vașl (<Ar.) Kavuşma.

$$
\text { v.+1ipla (vacda-1 v.) } 71
$$

veh veh (Ünlem) Köpek, çakalın havlaması.

$$
\text { v. } 286
$$

ve $\quad(<A r) b$.$k . vu$

v. kim 129

vu (<Ar.) (Bağlama edatı) Ve. Krş. u, ü, ve

$$
\text { v. } 291
$$

yā (<Far.) (Bağlaç) Ya.

y. ki Veya, yahut. 62

yā $\quad(<A r$.$) Ey.$

y. Rab "Ey Allahım, ey Rabbim, ey Tanrım" anlamında olan bu söz Allah'tan yardım isteme, şaşkınlık, korku vb. durumlarda ve Allah'a sığınma ifadesi olarak kullanılır. 66

yag- Yağmak.

y.-1ban (yağış y.) 296

yag̉ış Yağmur.

y. yag- 296

yaman Kötü, fena.

y. 271

yayak Yanak.

y. $+\operatorname{din} 41$

yaylıㅕibi, benzer.

y. 167

yār (<Far.) Sevgili.

y. 06

y.-1 sarv-ı kāāmat 286

y. + in 76

yarat-Yaratmak.

y.-̇̈an 290

yarlıg Ferman.

y. 291

yastan- Uzanmak, yaslanmak.

y.-mak 294

yatīmī $(<$ Ar. yetīm) Bir yetim.

y. ḳal- Yetim kalmak. 62

yektā (<Far.) Tek, eşsiz, benzersiz.

$$
\text { y. (hudā-yı ahad-ı y.) } 138
$$

yer Yer.

$$
\begin{aligned}
& \text { y. } 290 \\
& \text { y.+de } 315 \\
& \text { y.+e } 66
\end{aligned}
$$

y.+ge 315

y. ü kök 167

yér bk. yer

y.+idin 54

yet- Sonlanmak, tamamlanmak.

y.-ti 315

yéti Yedi.

y. 68

yetiş- Ulaşmak.

y.-tim 257

yı ̇̀la- Ağlamak.

y.-p 06

yok Yok.

y. 115

$\operatorname{yosun}(M o \breve{g}$.) Usul, şekil, tarz.

y. 66

yüz Yüz (sayı).

y. 185

zāhidī $(<A r$.$) Bir zahit.$

Z. 10

zamzam (<Ar. zemzem) Kâbe yanındaki meşhur kuyudan çıkan kutsal su.

z. +da (kenar-1 çāh-1 z.)+da 33

zlyād ( $<$ Ar. ziyād) Artma, fazlalık.

Z. 185

ziyārat (<Ar.ziyāret) Ziyaret.

z. ét- Ziyaret etmek. 58

\section{3. Özel Adlar Sözlüğü}

Āmū y.a. Ceyhun, Batı Türkistan'da Pamir yaylasının güneyinden doğup Tacikistan ve Afganistan topraklarını ayırarak Tirmiz'den aşağıda Türkmen çölüne girip geniş bir delta ile Aral gölünde sona eren $2620 \mathrm{~km}$ uzunluğundaki bir ırmak. 296

Aras y.a. Aras nehri. Türkiye-Azerbaycan, TürkiyeErmenistan ve Azerbaycan-İran sınırının bir bölümü oluşturduktan sonra Azerbaycan'da Kura Nehri'ne dökülen nehir. 1072 km uzunluğunda, 102 bin $\mathrm{km}^{2}$ havza alanına sahip nehir Kafkaslar'ın en büyük nehirlerinden biridir. 296

Balh y.a. Belh şehri, bugün Afganistan'ın kuzeyinde bulunan vilayet.

b. + da 286

Çaġatay ö.a. Çăgatay, Cengiz Han'ın ikinci oğlunun ismi. Şeyh Süleyman Efendi sözlüğünde "Çaġatay" madde başına "Cengiz Han'ın üçüncü oğlunun ismidir, Orta Asya'da bir rütbedir, Çağatay dili buna mensuptur. 
Sekkâkî bunun nedimidir. Vefâtı 638” karşıllğını vermiştir. (s.140)

ç. lafżı 291

ç. lısānı 315

Dekken y.a. 16. yüzyılda Hindistan Yarımadası'nda Behmenîlerin kurduğu devletin adı. Tarihte Hindistan'ın güney kesimine Dekken adı verilirdi. Bugün Hindistan'ın büyük bölümünü kaplayan üçgen biçimindeki yüksek ovaya Dekken Platosu adı verilmektedir.

d. 286

Harāty.a. Horasan bölgesinde bir yer.

h. +1286

Hınd y.a. Hindistan.

h. u Serhend 58

Hudāa (<Far.) ö.a. Allah.

h.--yı ahad-ı yektā 138

Kāâbıl y.a. Afganistan'ın başkenti.

k. + in 257

Kandahār y.a. Afganistan'da bir vilayet ismi.

k. 286

Kiş y.a. Şebz şehrinin ismi, Emir Timur'un doğduğu şehir.

k. 266

Nakşī ö.a. Şeyh Süleyman Efendi'nin mahlası.

n. 66

n. + din 185

Rab ö.a. Tanrı.

r. (yā Rab) 66

Rabġūzī ö. a. Harezm Türkçesi ile yazılmış Kısasu'lEnbiyâ adlı eserin yazarıdır. Şeyh Süleyman Efendi sözlüğünde onun şiirlerini de tanık olarak göstermiştir.

r. 129

Serhend y.a. Serhend (Sirhind), Delhi'nin $250 \mathrm{~km}$ kuzeyindedir. Delhi ve Lahor arasındakiyolda bulunur. Nüfusun çoğunluğunu Sihler teşkil etmektedir.

s. $+\mathrm{i} 58$

Teyri ö.a. Tanrı.

t. 4

t.-yi bī-hem-tā 138

Tilev ibn Kılıc ö.a. "Tilev" Özbek kabilelerinden birinin adı olup kişi adı olarak da kullanılmaktadır. Tilev sözcüğünün "dilek, arzu", "kahraman, pehlivan" gibi anlamları da vardır.

t. (Tilev ibn Ḳlıc) 4 


\section{Sonuc}

Din adamı, elçi, diplomat, leksikograf olarak tanınan Şeyh Süleyman Efendi’nin şair kimliği gölgede kalmış, Nakşî mahlaslı şiirleri üzerine kapsamlı bir çalışma yapılmamıştır. Edebiyat mahfillerinde şeyhin kendi şiirlerinin yer aldığı bir eser yazdığı hakkında bir bilgi yoktur. Matbaacıllğı öğrenerek Orta Asya şairlerinin eserlerini yayımlayan, Çağatay Türkçesini ve Çağatay edebiyatını tanıtmayı kendine görev edinen Şeyh Süleyman Efendi’nin neden kendi şiirlerini derleyip basmadığı bilinmemektedir. Şeyhin kendi şiirlerini bir kitapta toplamayıp Venedik’te yazdığı şiirlerinin bir kısmını Macarcaya çevirmesi için Dr. Béla Erödi’ye göndermesi hayli ilginçtir. Bu durum şiirlerine sadece sözlüğündeki örneklerde ve mukaddimesinde yer veren çok yönlü dervişin şeyhlik, elçilik, diplomatlık gibi diğer kimliklerinin vaktinin büyük bir kısmını aldığını, Lugat-i Çağatay ve Türk̂̂-i Osmân̂̀nin ikinci cildini dahi bitiremediği ihtimalini akıllara getirmektedir.

$\mathrm{Bu}$ çalışmanın amacı ruhani kimliğinin kendisi gibi Orta Asyalı dervişler üzerindeki tesiri, dinî ve ilmî alanlardaki hâkimiyeti ile dikkatleri üzerine çeken Buharalı Şeyh Süleyman Efendi’nin bilinmeyen bir yönünü ortaya çıkarmak, Lugat-i Çağatay ve Türkî-i Osmân̂̂ye tanık olarak katkılarını ve zengin sözcük dağarcığına sahip bir leksikografın şiirlerindeki sözcük seçimini tespit etmektir. Lugat-i Çağatay ve Türkî-i Osmânînin tamamı taranarak her firsatta şiir okuduğu ve yazdığı ifade edilen Şeyh Süleyman Efendi'nin sözlüğünde otuz üç madde başına tanık olarak kendi şiirlerini gösterdiği, bunların bazılarında Nakşî mahlasını kullanırken, manzum mukaddimesinden alıntıladığı beyitlerde mahlasını kullanmaya gerek görmediği tespit edilmiştir. Çalışmanın ilk bölümünde Şeyh Süleyman Efendi’nin şair kimliğini ve şiirlerindeki otobiyografik unsurları anlayabilmek, şiirlerine bütünlüklü yaklaşabilmek, sözlüğünün şiirleriyle şekil ve dil özellikleri açısından benzerlikler taşıdığını ifade edebilmek için Şeyh Süleyman Efendi ve Lugat-i Çağatay ve Türkî-i Osmân̂̂’ ile ilgili bilgilere yer verilmiştir. Çalışmanın ikinci bölümünde Şeyh Süleyman Efendi’nin tanık olarak gösterdiği şiirleri madde başlarına verilen tanımların altında sözlükteki sayfa numarası belirtilerek sıralanmış, şiirlerin üslup ve dil özellikleri üzerine değerlendirmelerde bulunulmuş, şiirlerde geçen bütün sözcüklerin dizini ve özel adlar sözlüğü hazırlanmıştır. Dizin ve özel adlar sözlüğü Şeyh Süleyman Efendi’nin kendi sözlüğünde bulunmayan sözcükleri de tercih ettiğini göstermesi ve söz varlığına dair fikirler vermesi açısından önemlidir.

Şeyh Süleyman Efendi'nin şiirlerinde otobiyografik unsurların etkisi hissedilmektedir. Şiirlerindeki söz varlığı onun günlük dilden ve halk kültüründen beslendiğini, Orta Asya kültürüne, coğrafyasına, edebiyatına hâkim olduğunu, iyi bir eğitim aldığını göstermektedir. Son dönem Çağatay Türkçesinin özelliklerini taşıyan şiirlerinde Oğuzca unsurlar da görülmektedir. Şiirleri sözlüğe yöneltilen eleştirilerden imlâ tutarsızlığını ve maddi imlâ hatalarını örnekler niteliktedir. Şiirlerinde başta Ali Şir Nevâyî olmak üzere Çağatay ve Divan edebiyatının güçlü şairlerinin etkilerini görmek mümkündür. Şeyh Süleyman Efendi’nin deyimlerden, ilişki sözlerinden, Arapça, Farsça, Moğolca kökenli alıntı sözcüklerden, Çağatay Türkçesinin söz varlığından, özel adlardan yararlandığı, aruz ölçüsünün daha çok remel ve hezec bahirleriyle yazdığı, uyağa önem verdiği, teşbih, mübalağa, telmih, sihr-i helâl gibi söz sanatlarını kullandığı görülmektedir.

\section{Kaynakça}

\section{Arşiv belgeleri}

BOA, KK. d., nr.6290/1, 158

BOA, MVL, nr. 485/109

BOA, HR.TO, nr. 511/26 


\section{BOA, MF.MKT 3/75}

\section{Elektronik kaynakça}

http://earsiv.sehir.edu.tr:8080/xmlui /handle/11498/4444?locale-attribute=tr/[Erişim Tarihi: 02.11.2018]

https://acikerisim.tbmm.gov.tr/ xmlui/handle/11543/1076) [Erişim Tarihi: 22.12.2018]

http://www.fatih.bel.tr/assets/file/KitabelerinKitabiFatih/kitabelerinkitabifatih.pdf [Erişim tarihi: 02.02.2018]

http://www.tdk.gov.tr/index.php?option=com_bts\&view=bts [Erişim Tarihi: 10-20 Şubat 2018]

\section{Kitap ve makaleler}

Ahmed Vefik Paşa. (1308). Lehce-i Osmânî (2. baskı), İstanbul: Mahmud Bey Matbaası.

Akçuraoğlu, Y. (2015). Türkçülüğün Tarihi, İstanbul: Ötüken.

Argunșah, M. (1991). “15.yy'da Yazılmış Tuhfe-i Murâdî İsimli Cevhernâme'de Geçen Değerli Taşlarla İlgili Terimler”, Marmara Üniversitesi Türklük Araştırmaları Dergisi, S. 6, İstanbul: Edebiyat Fakültesi Basımevi, 1-20.

Atik, H. (2005). "Türk Edebiyatında Nakşî Mahlaslı Şâirler”, İstem, Yıl:3, S. 5, 169-180.

Ayverdi, İ.; Topaloğlu A. (2010). Misalli Büyük Türkçe Sözlük, İstanbul: Kubbealtı.

Bektaş, C. (1984). "Üsküdar'ın Sultantepesindeki Özbekler Tekkesi", Tarih ve Toplum, S. 8, 40-45.

Béla, E. (1877). Csok Jasa! A Török Küldöttség Látogatásának Emlékkönyve, (Türk Heyetinin Ziyaretinden Hatıra Kitabı), (çev. Yılmaz Gülen), Mehner Vilmos Kiadványa, Budapest.

Bozdă̆, İ. (1992). Sultan Abdülhamid’in Hattra Defteri, İstanbul: Pınar.

Caferoğlu, A. (1984). Türk Dili Tarihi I-II, 3. Baskı, İstanbul: Enderun Kitabevi.

Cihani, H. A. (1392). Ferhang-i Cağatayi-Farsi: Eser-i Şeyh Süleyman Efendi-yi Özbeki el-Buhari, Tebriz: Denizçin Yay.

Clauson, Sir G. (1960). Sanglax, A Persian Guide to theTurkish Language by Muhammad Mehdī Xān, (FaksimileText with an Introduction an Indices by Sir Gerard CLAUSON), London (Seng.)

Clauson, G. (1972). An Etymological Dictionary of Pre-Thirteenth-Century Turkish, Oxford: Oxford University Press.

Courteille, P. de. (1870) Dictionnaire Turc-Oriental, Paris.

Çakan, V. (2005). "Hoca Ahmed Yesevi ve Divân-ı Hikmet”, Millî Folklor, Yıl 17, Sayı 68, 201-207.

Çetinsaya, G. (1988). II. Abdülhamid’in İlk Ylllarında İslam Birliği Hareketi (1876-1878), (Yayımlanmamış Yüksek Lisans Tezi), Ankara: Ankara Üniversitesi Sosyal Bilimler Enstitüsü.

Durgut, H. (1995). Şeyh Süleyman Efendi-i Buhari Lügat-ı Çağatay ve Türki-i Osmani (Cild-i Evvel) Adlı Eserin Transkripsiyonu, (Yayımlanmamış Yüksek Lisans Tezi), Edirne: Trakya Üniversitesi Sosyal Bilimler Enstitüsü.

Eckmann, J. (2017). Çağatayca El Kitabı, (çev. Günay Karaağaç), Ankara: TDK.

Eckmann, J. (1996). Harezm, Kıpçak ve Çağatay Türkçesi Üzerine Araştırmalar, (Yayıma Hazırlayan: Osman Fikri Sertkaya), Ankara: Türk Dil Kurumu Yay.

Eminoğlu, E. (2011). “Sözlükçülük Geleneği İçinde Temel Türkçe Sözlük Düzenleme Yöntemleri”, Dil ve Edebiyat Araştırmaları Dergisi, S. 4, Yaz, 93-121.

Eraslan, K. (1970). "Doğu Türkçesinde Ek Uyumsuzluğuna Dair”, Türk Dili ve Edebiyatı Dergisi, S. XVIII, 113-124. 
Erbay, F. (2008). "W. Radloff'un Sözlüğündeki Çağatay Türkçesine Ait Kelimelerde Karşlaşılan Bazı Sorunlar", 1. Uluslararası Türk Dili ve Edebiyatı Sempozyumu Bildirileri, (23-26 Ekim 2007), Isparta, 245-250.

Erbay, F. (2010). "Gölge Kelime” Terimi ve Çağatayca Sözlüklerdeki Bazı Gölge Kelimeler”,Turkish Studies, Volume 5/3 Summer, 1175-1186.

Eren, H. (1950). “Çağatay Lügatleri Hakkında Notlar”, Ankara Üniversitesi DTCF Dergisi, C. 8, S. 1-2, Ankara, 145-163.

Gölpınarlı, A. (1951). Nedîm Dîvânı, İstanbul: İnkılâp Kitabevi.

Gülsevin, G. (2007). “Oğuzca Olmayan Tarihî Metinlerde Oğuzca Unsurlar ve Nehcü'l-Feradis Örneği”, 46th Meeting of Permanent International Altaistic Conference, Ankara, 22-27 Haziran 2003. (Basılmış şekli: Uluslararası Sürekli Altayistik Konferansı Bildirileri, Altay Dünyasında Gündelik Hayat, Türk Dil Kurumu Yayınları, Ankara, 163-175).

Hazar, M. (2011). “Çağatay Türkçesinde Oğuzca Özellikler ve Benzerlikler”, JASSS, Volume 4, Issue 1, 31-63.

Kaçalin, M. S. (2009). "Lugât-ı Çağatay ve Türkî-i 'Osmânî Üzerine”, Ahmet Yesevi Üniversitesi III. Uluslararası Türkoloji Kongresi, (18-20 Mayıs 2009), Türkistan, 106-117.

Kaçalin, M. S. (2011). Niyazi-Nevâyînnin Sözleri ve Çağatayca Tanıklar- El-Lugatu'n-Nevaiyye ve'lİstişhadatu'l-Cagata’iyye, Ankara: Türk Dil Kurumu Yay.

Kara, F. (2011), Muhammed Yaḳub-ı Çingī, Zebân-ı Türkî (Kélür-nâme), İnceleme-Metin-Dizin. Erzurum: Fenomen.

Kara, M. (1998). “Mahdum Kulu’nun Şiirlerinde Çağatayca ve Oğuzca Unsurlar”, Bilig, Sayı 7, 131-135.

Kaymaz, Z. (2014). "Çağatay Türkçesindeki Oğuzca Unsurlar Üzerine”, C. Amanjolov Okuvlarl-Attı Halkaralk Gilımi-Praktikalik Konferentsiyanın Materiallar, Kazakistan/Öskemen, 204-210.

Kitabelerin Kitabı Fatih İlçesi Türk İslam Devri Kitabeler Envanteri (2016). İstanbul: Fatih Belediye Başkanlığı.

Kúnos, I. (1902). Țejx Sülejman Efendi's Čagataj-Osmanisches Wörterbuch, Budapest.

Kushner, D. (1998), Türk Milliyetçiliğinin Doğuşu, İstanbul: Fener.

Levend, A. S. (1972). Türk Dilinde Gelişme ve Sadeleşme Evreleri, Ankara: Türk Dil Kurumu.

Mehmed Tevfik, (1877).Yadigâr-ı Macaristan Asr-ı Abdülhamid Han, İstanbul: Mihran Matbaası.

Muallim Naci. (1904). Lügat-i Nâcî, İstanbul: Asır Matbaası.

Nalbant, B. (2017). “Türkistan, İran ve Anadolu Sahasında Yazılan Doğu (Çağatay) Türkçesi Sözlük ve Gramerleri”, Modern Türklük Araştırmaları Dergisi, C. 14. S. 4. Aralık, 120-147.

Ölmez, Z. (1998). “Çağatayca Sözlükler”, Kebikeç, S. 6, 137-144.

Özcan, A. (1992). "Özbekler Tekkesi Postnişini Buharalı Şeyh Süleyman Efendi Bir double agent mı idi?”, Tarih ve Toplum, XVII/100, 12-16.

Rahimi, F. (2018). “Çağatay Türkçesi Sözlükleri Bibliyografyası”, Uluslararası Türkçe Edebiyat Kültür Ĕ̆itim Dergisi, 7 (1), 69-104.

Redhouse, J. W. (1890). A Turkish and English Lexicon: Shewing in English the Significations of the Turkish Terms, İstanbul: American Mission.

Sami, Şemseddin. (2006). Kâmûs-ı Türkî. (On Beşinci Baskı), İstanbul: Çağrı Yayınları.

Saral, İ. T.; Saral, E.; Sezer, F. (2009). "Çaylak" Mehmet Tevfik Yadigar-ı Macaristan Asr-ı Abdülhamid Han, Ankara: Türk-Macar Dostluk Derneği Yayınları:7.

Smith, G. M. (1980). "The Özbek Tekkes of Istanbul." Der Islam; Zeitschrift für Geschichte und Kultur des Islamischen Orients 57, 129-139. 
Steingass, F. (1998). A Comprehensive Persian-English Dictionary, Beirut: Librairie du Liban Publishers.

Süreyya, Mehmed (1311). Sicill-i Osmânî, C. III, İstanbul: Matbaa-i Amire.

Szlágyl, S. (2007). Ignác Kúnos Türk Folklor Araştırmalarında Bir Öncü, (Yayımlanmamış Yüksek Lisans Tezi), Ankara: Ankara Üniversitesi Sosyal Bilimler Enstitüsü.

Şafak, N. (2009). "Buhara Özbekler Tekkesi”, DEM dergi, Yıl 2, S. 5, 142-147.

Şen, Mesut. (2014). “Tanzimat Aydınlarının “Çağatay Türkçesi”ne Bakışı ve Şemseddîn Sâmî’nin Tesiri”, Turkish Studies -International Periodical For The Languages, Literature and History of Turkish or Turkic, Volume 9/9 Summer, Ankara, 81-102.

Şeyh Süleyman Efendi-i Özbekî el-Buhârî. (1882). Lugat-i Çağatay ve Türkî-i Osmân̂̀, İstanbul: Mihrân Matbaası.

Tanman, M. B. (2007). “Özbekler Tekkesi”, İslam Ansiklopedisi, C. 34, 121-123.

TDTC (Türk Dili Tetkik Cemiyeti) (1934) Osmanlıcadan Türkçeye Söz Karşıllkları Tarama Dergisi I,II., İstanbul: Devlet Matbaası.

Topaloğlu, A.; Kaçalin, M. S. (2009). "Sözlük”, TDV İslâm Ansiklopedisi, C. 37, 402-414.

Yaman, E. (2007). "Süleyman Efendi", Türk Dünyası Edebiyatçlları Ansiklopedisi, C. VII., Ankara: Atatürk Kültür Merkezi.

Yılmaz, S. (2007), Özbek Tekkeleri, (Yaymlanmamış Yüksek Lisans Tezi), Sakarya: Sakarya Üniversitesi Sosyal Bilimler Enstitüsü.

Yllmaz, S. (2016). M. Pavet De Courtelle’nin "Dıctıonnarre Turk-Orıental” Adlı Sözlüğünün Türkiye Türkçesine Çevirisi ve Leksikolojik İncelemesi, (Yayımlanmamış Yüksek Lisans Tezi), Ordu: Ordu Üniversitesi Sosyal Bilimler Enstitüsü.

Yeşilot, O.; Çelik, Y. vd. (komisyon). (2015). İstanbul'daki Türkistan Tekkeleri Ata Yurt ile Ana Yurt Arasındaki Manevi Köprüler, Türbeler Çeşmeler Taşınır Taşınmaz Kültür Varlıklarını Koruma ve Yaşatma Derneği, İstanbul: Şekil Ofset.

Zarcone, T. (2008). "Doğulu ve Batılı Yolcuların İntibalarında Buhara Tekkesi”, 3.UluslararasıTarihi Yartmada Sempozyumu Tebliğler Kitabı, İstanbul Eminönü Belediyesi., 52-59. 